\title{
SUGGESTED MODEL TO ESTIMATE IRRIGATION WATER REQUIREMENT FOR SOME CROPS IN SANDY SOIL - WADI EL NATRUN - EGYPT
}

\author{
Ali Ahmed Ali Abdel-Aziz*
}

\begin{abstract}
An experiment was performed during two winter successive seasons of (2016/2017-2017/2018), at a private farm in Wadi El-Natrun area, ElBehera Governorate, Egypt, to study the effect of applied irrigation water (IR) methods: fuzzy Logic controller (FLC) and manual irrigation water addition (Manual) based on ETc100\% at different humic acid rates " $H A$ " (10, 15 and $\left.20 \mathrm{~kg} \mathrm{ha}^{-1}\right)$ under surface and sub-surface drip irrigation systems on marketable yield, crop quality parameters, actual evapotranspiration (ETa), water use efficacy (WUE) and irrigation water use efficiency (IWUE) for sugar beet roots and spinach leaves crops under surface (SDI) and sub-surface drip (SSDI). The results showed that, the marketable yield and studied quality parameters of sugar beet roots and spinach leaves gave the highest values under FLC and SSDI treatment for both seasons. While, the seasonal ETa of sugar beet and spinach crops gave the lowest values: 436.24 and $141.82 \mathrm{~mm} ; 429.16$ and $139.93 \mathrm{~mm}$ for both seasons respectively, under FLC and SSDI treatment. The results recorded that, the marketable yield and studied quality parameters of sugar beet and spinach crops gave the highest values under FLC, HA =20 $\mathrm{kg} \mathrm{ha}^{-}$ ${ }^{1}$ and SSDI treatment for both seasons. While, the IR and ETa of both crops gave the lowest values under FLC, HA $=15 \mathrm{~kg} \mathrm{ha}^{-1}$ and SSDI treatment. Finally, the WUE and IWUE of both crops gave the highest values under FLC, HA $=15 \mathrm{~kg} \mathrm{ha}^{-1}$ and SSDI treatment. This study concluded that the cultivation of sugar beet and spinach crops under FLC, HA =15 $\mathrm{kg} \mathrm{ha}^{-1}$ and SSDI treatment can possibly save of the applied irrigation water about 35 and $45 \%$ for the $1^{\text {st }}$ season while, were 41 and $47 \%$ for the $2^{\text {nd }}$ season respectively, moreover, increased marketable yield 35 and $45 \%$ for the $1^{\text {st }}$ season while, were 41 and $47 \%$ for the $2^{\text {nd }}$ season respectively, compared with that under the control treatment (Manual, HA $=20 \mathrm{~kg} \mathrm{ha}^{-1}$ and SDI treatment).
\end{abstract}

Keywords: Fuzzy Logic controller; Water use efficiency; Irrigation water use efficiency, applied irrigation water.

*Soil Chemistry and Physics Department - Desert Research Center. 


\section{INTRODUCTION}

$\mathrm{T}$ The farmers manually control the water supply by tabulating the irrigation time of the croups. These process not accurate irrigation amounts of water loosed. For this reason an automatic irrigation system based on sensing technology is required to reduce the cost and to give uniformity in water application across the field (Khan et al., 2014). Conventional method such as on-off control method or proportional control method basically results in a loss of energy and productivity. In order to maximize the efficiency and production for irrigation system, the fuzzy logic controller is proposed to estimate the amount of water for plants in distinct depth using the irrigation model, soil type, environmental conditions and type of plant that affecting the irrigation system. The comparison simulation results between the fuzzy logic controller and onoff controller had shown that on-off controller based system fails miserably because of its limitations. The irrigation based fuzzy logic controller system operates within the proper range and is stable. Consequently, fuzzy controller system had more ability as compared with other system. It is important to note that such system can save a lot of water, increase productivity and very easy to implement. Furthermore, the fuzzy rules are simple, therefore making the system attractive to use by researchers, engineers and agriculturists (Hussain et al., 2011). Fuzzy control algorithm was put in details which included the setting of input and output, the chosen of membership function and the setting of fuzzy rules. The fuzzy logic model was significant for the intelligent saving of irrigation water in greenhouse (Ronghua et al., 2016). Fuzzy Logic controller (FLC) based on fuzzy set theory. This set theory is advanced version of classical set theory called crisp theory. In crisp set theory, an element either belongs to or does not belong to a set. But fuzzy set supports a flexible sense of membership of elements to a set. Many degrees of membership, between 0 and 1 , are allowed. The membership function is associated with a fuzzy set in such a way that the function maps every element of the universe of discourse or the reference set to the interval $[0,1]$. In crisp logic, the truth values acquired by propositions or predicates are two-valued, namely TRUE or FALSE which may be treated numerically equivalent to $(0,1)$. However, in fuzzy logic, truths values are multi valued such as absolutely 
true, partly true, absolutely false very true, and so on and are numerically equivalent to any value in the range 0 to 1 . In general, a FLM is a nonlinear mapping of an input data vector into a scalar output. A FL maps crisp inputs into crisp outputs, and this mapping can be expressed quantitatively as $\mathrm{y}=$ $f(x)$. It contains four components: fuzzifier, fuzzzy rules, inference engine, and defuzzifier (Melendez et al., 2011). The irrigation controller designed by using MATLAB 2015a, fuzzy logic and Simulink tools books the temperature and soil moisture sensors are used for detect the water quantity present in agriculture and water level sensor used for detecting water level in tank the level gauge interfaced by electronic circuit worked as signal conditioner circuit the water from tanks controlled by solenoid valve which actuated by relay circuit open and close as the microcontroller output then the water transmitted to roots zone using pipes line for irrigation process . The data from plant farms transmitted to control room by wireless networks in which temperature and soil moisture sensors and water level can be monitored and controlled (Hamouda et al., 2017). A fuzzy logic controller has been implemented for monitored drip irrigation duration using as variables soil moisture degree and air temperature. It is important to note that such system can save a lot of water and is cheap to implement. The fuzzy rules are simple, therefore making the system attractive to use by all types of agriculturists. The drip irrigation cropping system is similar to but better than the conventional soil cropping system because it can be used to control crop growth through a regulated supply of water and nutrients (Eddahhak et al., 2013). Vegetable plants were irrigated by a controller based on the fuzzy logic methodology. In this system, the amount of water given to the crops depends on its size, moisture control of soil, which is affected by temperature of environment, sunshine, rainfall, humidity, and evaporation due to wind speed and water holding capacity. This study presents a low cost FLC based automatic irrigation system to irrigate the crop efficiently with water savings. This system will save the use of water and other nutrients efficiently to improve the yield of the crop (Anand and Perinbam, 2014). The sub-surface drip irrigation system entombed at 0.35 $\mathrm{m}$ let regular soil moisture; reduce evaporative loss and distribution water immediately to the plant root zone ameliorative vegetative growth and yield properties. So, it is recommended to apply subsurface drip irrigation system 
at a depth of $0.35 \mathrm{~m}$ to irrigated corn under Tunisian specific conditions at the Mediterranean region (Douh and Boujelben, 2011). The subsurface drip irrigation (SDI) has the potential to provide consistently high water use efficiency over traditional methods, including surface drip irrigation while conserving soil, water, and energy. The SDI systems have the capability of frequently supplying water to the root zone while reducing the risk of cyclic water stress that is typical of other irrigation systems. Various researchers have shown that crop yield and quality can be increased using SDI on major field crops including sugar beet (SakellariouMakrantonaki et al., 2002). The sugar beet roots recorded the highest percentages of extractable sugar (17.30 and $16.23 \%)$, purity (85.72 and $80.57 \%$ ) and sucrose percentage (20.17 and 20.08\%) for both seasons respectively, under $75 \%$ of irrigation water requirements (IWR) and drip irrigation treatment (Masri et al., 2015). The average amounts of water applied and actual consumptive use were 3374.76 and $1990.12 \mathrm{~m}^{3} \mathrm{fed}^{-1}$ for sugar beet. While, the maximum values of sugar beet WUE and IWUE

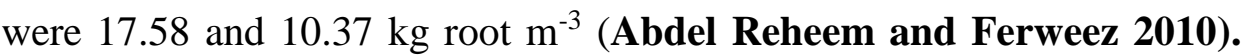
The addition of 5 liters ha ${ }^{-1}$ the humic acid for 3 times per season increases root yield and refined sugar yield by about 24 and 37\% respectively, compared to control treatment $\left(0 \mathrm{~L} \mathrm{ha}^{-1}\right)$, as the main of qualitative and quantitative parameters of sugar beet yield (Rassam et al., 2015). Spinach plant was irrigated with three amounts of applied irrigation water 100, 85 and 70\% of Epan, which were 290, 264.3 and $238.6 \mathrm{~mm}$, respectively for both seasons. The 100\% Epan treatment recorded the highest marketable yield $\left(28.06 \mathrm{t} \mathrm{ha}^{-1}\right)$ and IWUE $\left(9.7 \mathrm{~kg} \mathrm{~m}^{-3}\right)$, while $100 \%$ Epan treatment in spinach production could be proper for water enough regions due to higher yield and IWUE (Yasemin et al., 2016). The addition of 4 liters $\mathrm{fed}^{-1}$ of humic acid for three times in 15 days interval increased all growth parameters of spinach plants, as plant length, number of leaves/plant, fresh and dry weight of leaves as well as total chlorophyll content and total yield. Results recorded the high N, protein, $\mathrm{p}$ and $\mathrm{K}$ content in leaves spinach plant. On the other hand, the ratio of oxalates and nitrates in spinach leaves decreased by increasing the addition of humic acid (Hafez et al., 2015). This study aimed to investigate the effect of applied irrigation methods: (fuzzy Logic controller and manual of irrigation water addition) at different 
application humic acid rates under surface and sub-surface drip irrigation systems on sugar beet roots and spinach crops production, quality growth parameters, actual evapotranspiration, water use efficiency and irrigation water use efficiency.

\section{MATERIALS AND METHODS}

\section{1- Experiments layout:}

Field experiments were performed in Wadi El-Natrun area, El-Behera governorate, Egypt, at $30^{\circ} 23^{\prime} 09^{\prime \prime} \mathrm{N}$ : $30^{\circ} 25^{\prime} 31^{\prime \prime}$ E. 23 m b.s.l during two winter successive seasons of 2016/2017 and 2017/2018. In split-split plot design with three replicates, the experimental was divided into $50 \mathrm{~m}^{2}$ plots; each bounded by $1.5 \mathrm{~m}$ wide barren to avoid horizontal infiltration. The obtained data were subjected to statistical analysis according to Snedecor and Cochran (1989), using Co-state software program. The sugar beet (Beta Vulagaris L.) and spinach (Spinacia Oleracea L.) were irrigated by two methods: Fuzzy Logic controller (FLC) and manual of irrigation water addition (Manual) based on ETc100\% and application three humic acid rates "HA" $\left(10,15\right.$ and $\left.20 \mathrm{~kg} \mathrm{ha}^{-1}\right)$ under surface (SDI) and sub- surface drip (SSDI).

Sucrose (S) \%, purity of juice (P) \%, total soluble solid (TSS) \% and white sugar yield (WSY) $\mathrm{Mg} \mathrm{ha}^{-1}$ were determined for sugar beet roots. While, the leaf area (LA) $\mathrm{cm}^{2}$, calcium content (Ca) $\mathrm{mg} 100 \mathrm{~g}^{-1} \mathrm{FW}$ (Fresh Weight), vitamin C content (VC) mg $100 \mathrm{~g}^{-1} \mathrm{FW}$ and $\beta$ carotene content $(\beta \mathrm{C}) \mathrm{mg} 100 \mathrm{~g}^{-1} \mathrm{FW}$ were determined for spinach plant. Water use efficiency WUE $\left(\mathrm{kg} \mathrm{m}^{-3}\right)$, irrigation water use efficiency IWUE $\left(\mathrm{kg} \mathrm{m}^{-3}\right)$ and actual evapotranspiration ETa $(\mathrm{mm})$, were calculated at different IR methods and "HA" rates under SDI and SSDI for sugar beet and spinach plots.

\section{Soil properties:}

Soil samples were collected for some physical and chemical soil properties. The methodological procedures were according to Page et al., 1982 and Klute, 1986, (Tables 1 and 2).

\section{Quality of irrigation water:}

Chemical analyses of the irrigation water were measured according to Ayers and Westcot, 1994, Table (3) 
Table (1): Some physical characteristics of experimental soil

\begin{tabular}{|c|c|c|c|c|c|c|c|c|c|c|c|c|}
\hline \multirow{2}{*}{$\begin{array}{c}\text { Soil } \\
\text { depth } \\
\text { (cm) }\end{array}$} & \multicolumn{5}{|c|}{ Particle size distribution \% } & \multirow[b]{2}{*}{$\begin{array}{l}\text { Textural } \\
\text { class }\end{array}$} & \multirow[b]{2}{*}{$\underset{\%}{\text { OM }}$} & \multirow[b]{2}{*}{$\begin{array}{c}\rho_{b} \\
\mathrm{~g} / \mathbf{c m}^{3}\end{array}$} & \multirow[b]{2}{*}{$\begin{array}{c}\mathrm{Ks} \\
\mathrm{cm} / \mathrm{h}\end{array}$} & \multirow[b]{2}{*}{$\begin{array}{c}\text { FC } \\
\%\end{array}$} & \multirow[b]{2}{*}{$\begin{array}{c}\text { WP } \\
\%\end{array}$} & \multirow[b]{2}{*}{$\underset{\%}{\mathrm{AW}}$} \\
\hline & $\begin{array}{c}\mathrm{C} . \\
\text { sand }\end{array}$ & $\begin{array}{c}\text { M. } \\
\text { sand }\end{array}$ & $\begin{array}{c}\text { F. } \\
\text { sand }\end{array}$ & Silt & Cla & & & & & & & \\
\hline $0-15$ & 12.45 & .62 & 3.19 & & & & & & & & 5.73 & \\
\hline & 13.19 & 57.95 & 3.43 & & & & .46 & 1.54 & 9.19 & & 51 & 10.46 \\
\hline & 14.21 & 56.71 & 4.56 & 13 & & & 0.34 & 1.56 & 8.74 & 14.89 & 5.27 & 9.62 \\
\hline $45-60$ & 15.23 & 54.86 & 5.31 & 13.82 & & LS & 0.27 & 1.59 & 8.21 & 14.34 & 5.09 & 9.25 \\
\hline
\end{tabular}

Table (2): Some chemical characteristics of experimental soil

\begin{tabular}{|c|c|c|c|c|c|c|c|c|c|c|c|c|}
\hline \multirow{2}{*}{ 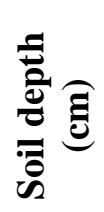 } & \multirow{2}{*}{ 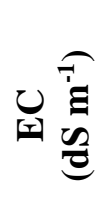 } & \multirow[b]{2}{*}{ 竞 } & \multirow{2}{*}{$\begin{array}{l}\delta^{\circ} \\
0 \\
0 \\
\tilde{U}\end{array}$} & \multirow{2}{*}{ 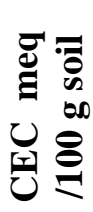 } & \multicolumn{8}{|c|}{ Soluble ions (meq/l) in the saturated soil paste } \\
\hline & & & & & $\stackrel{+}{+\pi}$ & $\stackrel{+}{ \pm}$ & \begin{tabular}{l} 
\pm \\
\multirow{0}{*}{} \\
\end{tabular} & $\sum^{+}$ & $\dot{\circlearrowright}$ & $\overbrace{}^{\prime}$ & రి & : \\
\hline $0-15$ & 1.87 & 7.89 & 2.91 & 6.43 & 8.87 & 0.85 & 5.42 & 3.56 & 9.21 & 2.63 & - & 6.86 \\
\hline $15-30$ & 2.02 & 7.85 & 2.86 & 6.29 & 9.65 & 0.98 & 5.76 & 3.81 & 10.04 & 2.87 & - & 7.29 \\
\hline $30-45$ & 2.24 & 7.73 & 2.73 & 5.87 & 10.23 & 1.32 & 6.61 & 4.24 & 11.39 & 2.98 & - & 8.03 \\
\hline $45-60$ & 2.31 & 7.71 & 2.68 & 5.65 & 10.51 & 1.38 & 6.84 & 4.37 & 11.75 & 3.04 & - & 8.31 \\
\hline
\end{tabular}

Table (3): Some chemical analysis for irrigation water

\begin{tabular}{|c|c|c|c|c|c|c|c|c|c|c|c|}
\hline \multirow{2}{*}{\multicolumn{2}{|c|}{ Sample pH }} & \multirow{2}{*}{$\begin{array}{c}\text { EC } \\
\text { dS m }^{-1}\end{array}$} & \multirow{2}{*}{ SAR } & \multicolumn{4}{|c|}{ Soluble cations, meq/l } & \multicolumn{4}{|c|}{ Soluble anions, meq/l } \\
\hline & & & & $\mathbf{N a}^{+}$ & $\mathbf{K}^{+}$ & $\mathbf{C a}^{++}$ & $\mathbf{M g}^{++}$ & $\mathrm{CL}^{-}$ & $\mathrm{HCO}_{3}^{-}$ & $\mathrm{CO}_{3}=$ & $\mathrm{SO}_{4}=$ \\
\hline Mean & 7.98 & 1.23 & 3.65 & 5.79 & 1.49 & 2.87 & 2.15 & 2.96 & 4.63 & - & 4.71 \\
\hline
\end{tabular}

\section{Irrigation water addition by used manual method TM:}

\subsection{Evapotranspiration ET:}

Both reference and crop evapotranspiration, ETo and ETc, respectively, shown in Tables (4 and 5) were calculated using Penman-Monteith equation FAO 56 method (Allen et al., 1998).

\subsection{Applied irrigation water IR:}

The amounts of applied irrigation water (IR) for winter sugar beet roots and spinach plant shown in table (5) were calculated by using the equation (Keller and Karmeli, 1974):

- $\left.\quad \mathrm{IR}_{\mathbf{1 0 0} \%}=(\mathrm{ETc}-\mathrm{pe}) \mathrm{Kr} / \mathrm{Ea}\right)+\mathrm{LR}$ $\left(\right.$ mm period $\left.^{-1}\right)$

Where: ETc, crop evapotranspiration, $\mathrm{mm} \mathrm{period}^{-1}$ 
$\mathbf{K r}$, correction factor for limited wetting according to the $80 \%$ sugar beet and spinach canopy coverage, $\mathrm{Kr}=0.90$. (Smith, 1992).

Ea, irrigation efficiency for drip, 85\% (Allen et al., 1998).

Pe, effective rainfall, $0 \mathrm{~mm}$ season $^{-1}$.

LR, leaching requirements, under salinity levels of irrigation water $(0.13$ x ETc $), \mathrm{mm}$.

Table (4): Calculated reference evapotranspiration ( $\left.\mathrm{mm} \mathrm{day}^{-1}\right)$ through winter sugar beet and spinach growth period.

\begin{tabular}{cccccccc}
\hline Month & Nov & Dec & Jan & Feb & Mar & Apr & May \\
\hline ETo mm day $^{-1}$ & 3.41 & 2.82 & 2.65 & 3.96 & 4.69 & 5.74 & 6.89 \\
\hline
\end{tabular}

Table (5): Calculated crop evapotranspiration (ETc) and applied irrigation water (IR), mm through winter sugar beet and spinach growth period.

\begin{tabular}{|c|c|c|c|c|c|c|}
\hline Crops & Stages & Initial & Develop. & Mid & Late & Seasonal \\
\hline \multirow{6}{*}{ Sugar beet } & Planting date & $2 / 11$ to $1 / 12$ & $2 / 12$ to $15 / 1$ & $16 / 1$ to $13 / 4$ & $14 / 4$ to $30 / 4$ & $2 / 11$ to $30 / 4$ \\
\hline & Period length (day) & 30 & 45 & 90 & 15 & 180 \\
\hline & $\mathrm{K}_{\mathrm{FAOO}}(-)$ & 0.35 & 0.78 & 1.20 & 0.70 & -ב----- \\
\hline & ETo (mm) & 101.12 & 124.18 & 386.08 & 86.1 & 697.48 \\
\hline & $\mathbf{E T c}_{100 \%}(\mathbf{m m})$ & 35.39 & 96.86 & 463.30 & 60.27 & 655.82 \\
\hline & $\mathbf{I R}_{100 \%}(\mathbf{m m})$ & 42.14 & 115.34 & 551.69 & 71.77 & 780.94 \\
\hline \multirow{6}{*}{ Spinach } & Planting date & $\begin{array}{c}2 / 11 \\
\text { to } 21 / 11\end{array}$ & $\begin{array}{c}22 / 11 \\
\text { to } 11 / 12\end{array}$ & $\begin{array}{l}12 / 12 \\
\text { to } 5 / 1\end{array}$ & $\begin{array}{c}6 / 1 \\
\text { to } 10 / 1\end{array}$ & $\begin{array}{c}2 / 11 \\
\text { to } 10 / 1\end{array}$ \\
\hline & $\begin{array}{l}\text { Period length (day) } \\
\end{array}$ & 20 & 20 & 25 & 5 & 70 \\
\hline & $\mathrm{Kc}_{\mathrm{FAO}}(-)$ & 0.70 & 0.85 & 1.00 & 0.95 & ------- \\
\hline & ETo (mm) & 68.20 & 61.12 & 69.48 & 13.25 & 212.05 \\
\hline & $\operatorname{ETc}_{100 \%}(\mathrm{~mm})$ & 47.74 & 51.952 & 69.48 & 12.5875 & 181.76 \\
\hline & $\mathbf{I R}_{100 \%}(\mathbf{m m})$ & 56.85 & 61.86 & 82.74 & 14.99 & 216.44 \\
\hline
\end{tabular}

Convert $\mathrm{mm}$ to $\mathrm{m}^{3}=$ water per $\mathrm{mm}$ depth $*$ Area (3.57 not 4.2 for drip irrigation)

5. Irrigation water addition by used Fuzzy Logic controller FLC:

\subsection{Implementation of controller hardware:}

\subsubsection{Environment temperature and relative humidity sensor:}

The HMP50 measures temperature with a $1000 \mathrm{Ohm}$ platinum resistance thermometer (PRT) measurement range of $-40^{\circ}$ to $+60^{\circ} \mathrm{C}$ and relative humidity $(\mathrm{RH})$ with a $50 \mathrm{Y}$ Intercap capacitive chip measurement range of 0 to $98 \%$ RH (non-condensing).The chip is field-replaceable, which eliminates the downtime typically required for the recalibration process. 
This temperature and RH sensor is compatible with all campbell scientific data loggers, as shown in Fig.1.

\subsubsection{Soil moisture sensor}

The mostly used sensor for soil moisture is ES1100 Watermark Sensor. Up to four ES1100 sensors can be connected to one eKo Node to measure soil moisture at different soil depths. By monitoring the sensor measurements between irrigations, it is possible to measure the rate at which the soil is drying out, as shown in Fig.2.

\subsubsection{Arduino Uno board}

This is the latest revision of the basic Arduino Uno board. It connects to the computer with a standard USB cable and contains everything else you need to program and use the board. It can be extended with a variety of shields: custom daughter-boards with specific features. It is similar to the Duemilanove, but has a different USB-to-serial chip the ATMega8U2, and newly designed labeling to make inputs and outputs easier to identify, as shown in Fig.3.

\subsubsection{Solenoid valve}

Solenoid control valve MV100 with high flow and low pressure loss for use in drip, spray, and pop up sprinkler watering systems. Valve has been designed to utilize a minimum number of internal parts to ensure reliability and cost effectiveness. MV100 Solenoid valve Consists of Magnetic stainless steel grade plunger, Stainless steel 302 plunger spring, Voltage $24 \mathrm{Vac} 50 \mathrm{~Hz}$ and Power consumption 4.5 VA. The valve will operate correctly with in the following conditions: Ambient temperature $2^{\circ} \mathrm{C}$ to $60^{\circ} \mathrm{C}$ Relative Humidity $0 \%$ to $100 \%$, as shown in Fig.4.

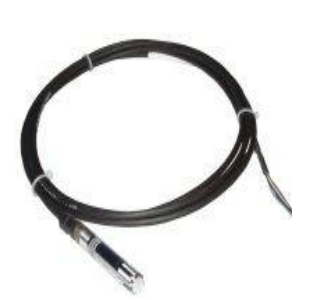

Fig. 1. Environment temperature and relative humidity

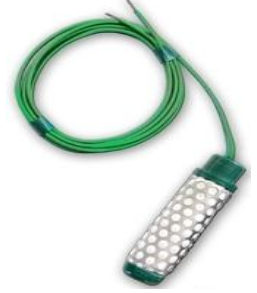

Fig. 2. Soil moisture sensor.

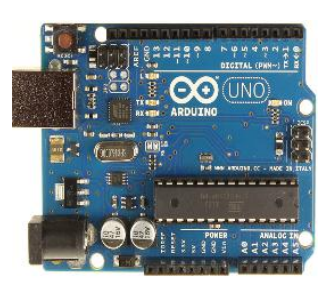

Fig. 3. Arduino Uno board.

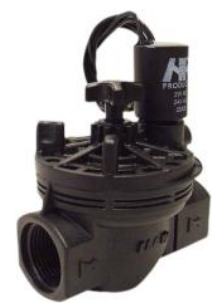

Fig. 4. Solenoid control valve.

\subsection{Fuzzy Logic controller FLC:}

The block diagram of FLC is showed in Fig.5 the fuzzy logic system included fuzzification by membership functions, rule base, a rule 
evaluation and aggregation and a defuzzification to create the crisp outputs. Three inputs selected were: 1) Environment temperature T, ${ }^{0} \mathrm{C} .2$ ) Environment relative humidity RH, \%. 3) Soil moisture content level Sm, centibars. The irrigation duration Dirr, minute was defined as a single fuzzy output variable. The range (universe of discourse) of the inputs and output variables was selected by examining data. The universe of discourse for $\mathrm{T}$, $\mathrm{RH}, \mathrm{Sm}$, and Dirr were $\left(0-50^{\circ} \mathrm{C}\right),(0-60 \%),(0-60 \mathrm{cb})$ and $(0-60 \mathrm{~min})$, respectively. The connection between inputs and output, both of which are 'crisp' values, is made via the linguistic transformation of input membership functions, implication and aggregation using the rule base, and defuzzification of the linguistic output to a numerical value representing irrigation duration.

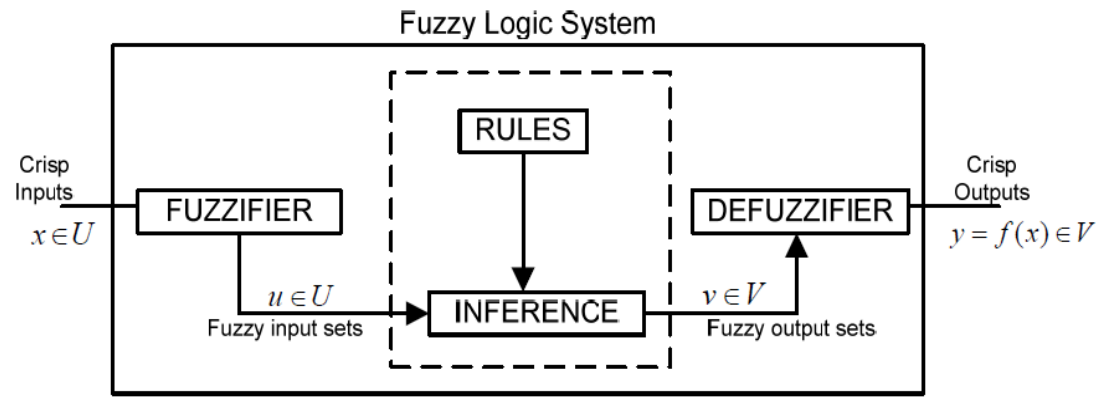

Fig. 5. Block Diagram of Fuzzy logic controller (Singh et al., 2013)

\subsection{Fuzzy Logic controller FLC design:}

In order to design the fuzzy logic controller for adding irrigation water there are four steps required as follow:

\section{Step 1: Identification of Control Surfaces:}

In this step, the linguistic variables are identified and membership values for each linguistic variable are calculated. The input and output variables are represented by fuzzy membership functions as shown in Fig. 6 - 9 suggested by author based on standard tables in FAO 65 for Temperature, Relative humidity and soil moisture content (Allen et al., 1998). The most commonly used membership functions were Gaussian, triangle and trapezoid so, as to simplify the computations.

\section{Step 2: Behavior of Control Surfaces:}

In this step fuzzy rules were built for various inputs to carry out several actions. Fuzzy inputs support with fuzzy output by fuzzy rules. The rule viewer is shown in Fig. 10 suggested by author. 


\section{IRRIGATION AND DRAINAGE}

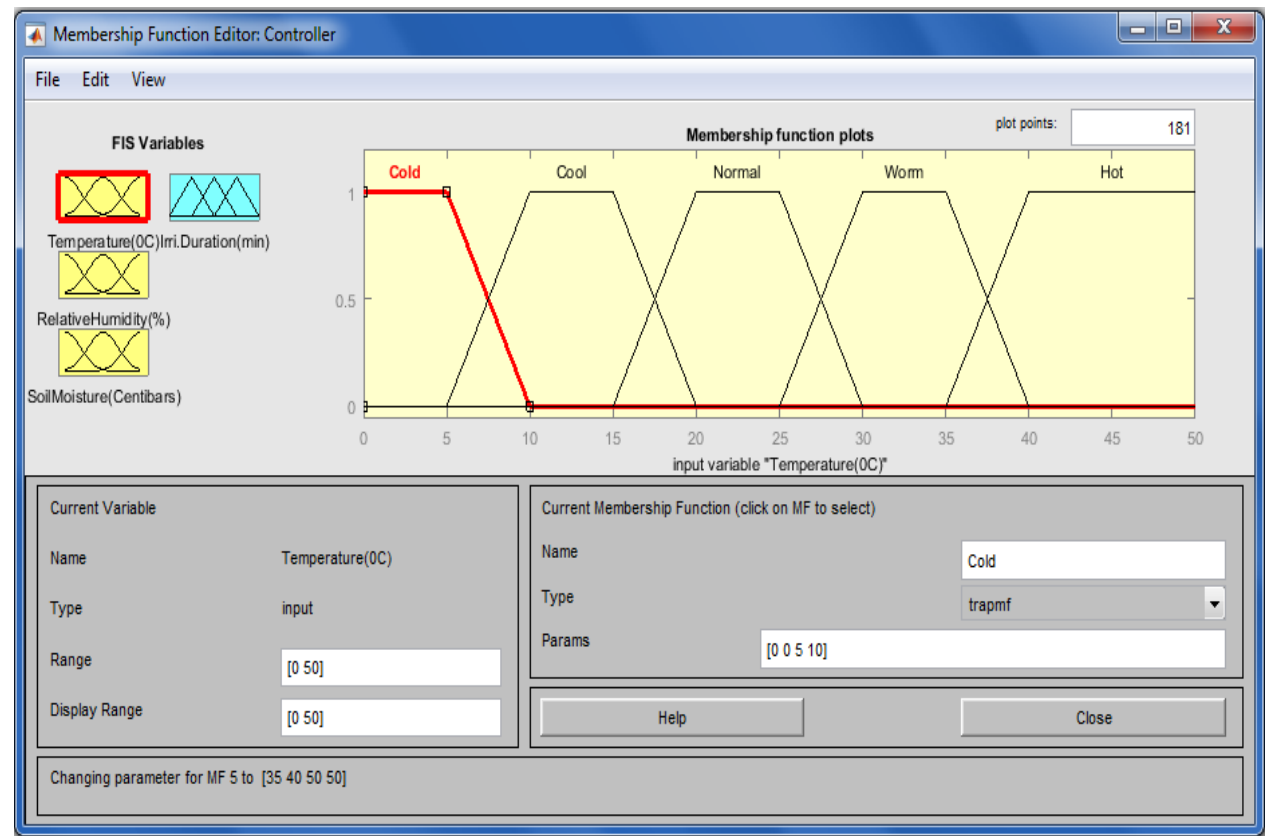

Fig. 6. Membership graph for input of environment temperature, ${ }^{0} \mathrm{C}$.

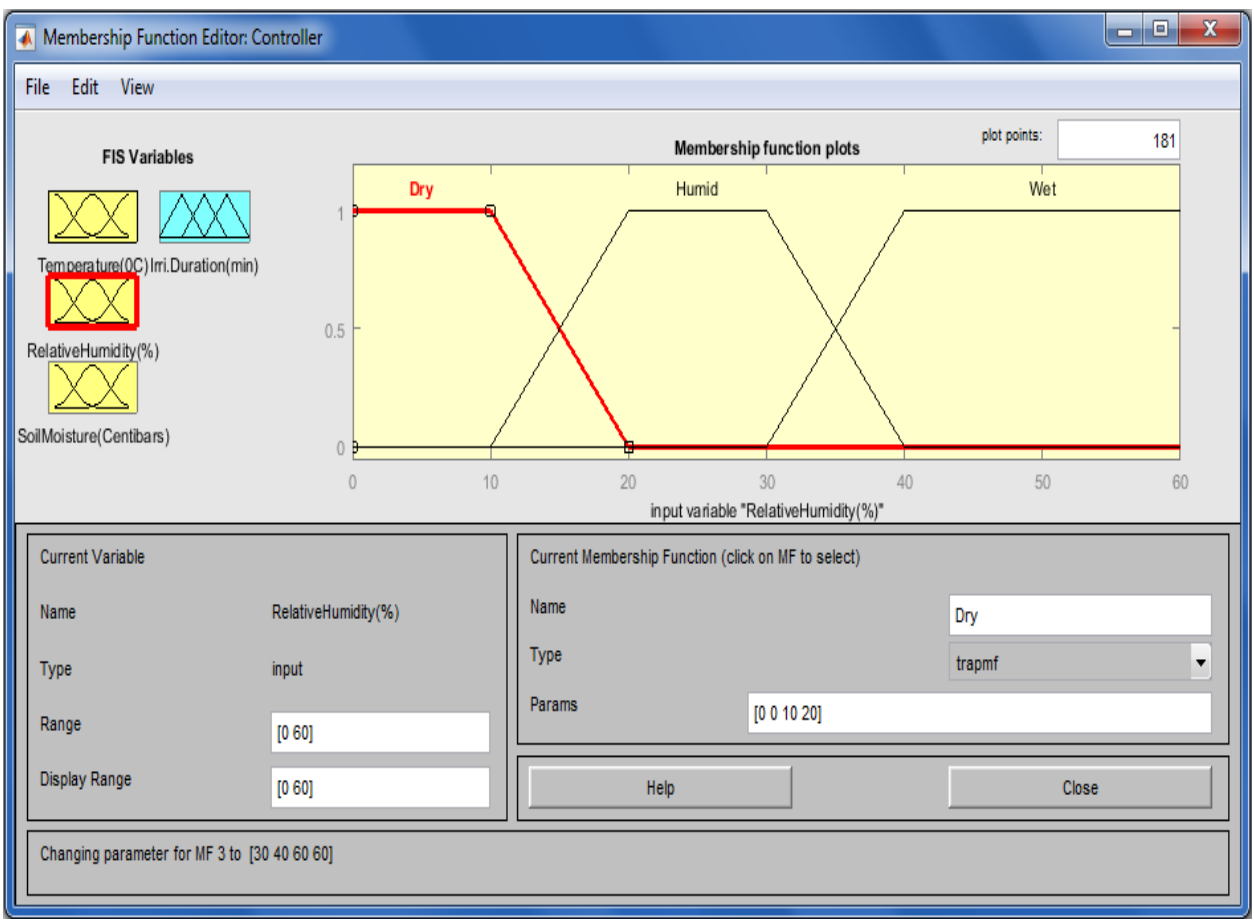

Fig. 7. Membership graph for input of environment relative humidity, $\%$. 


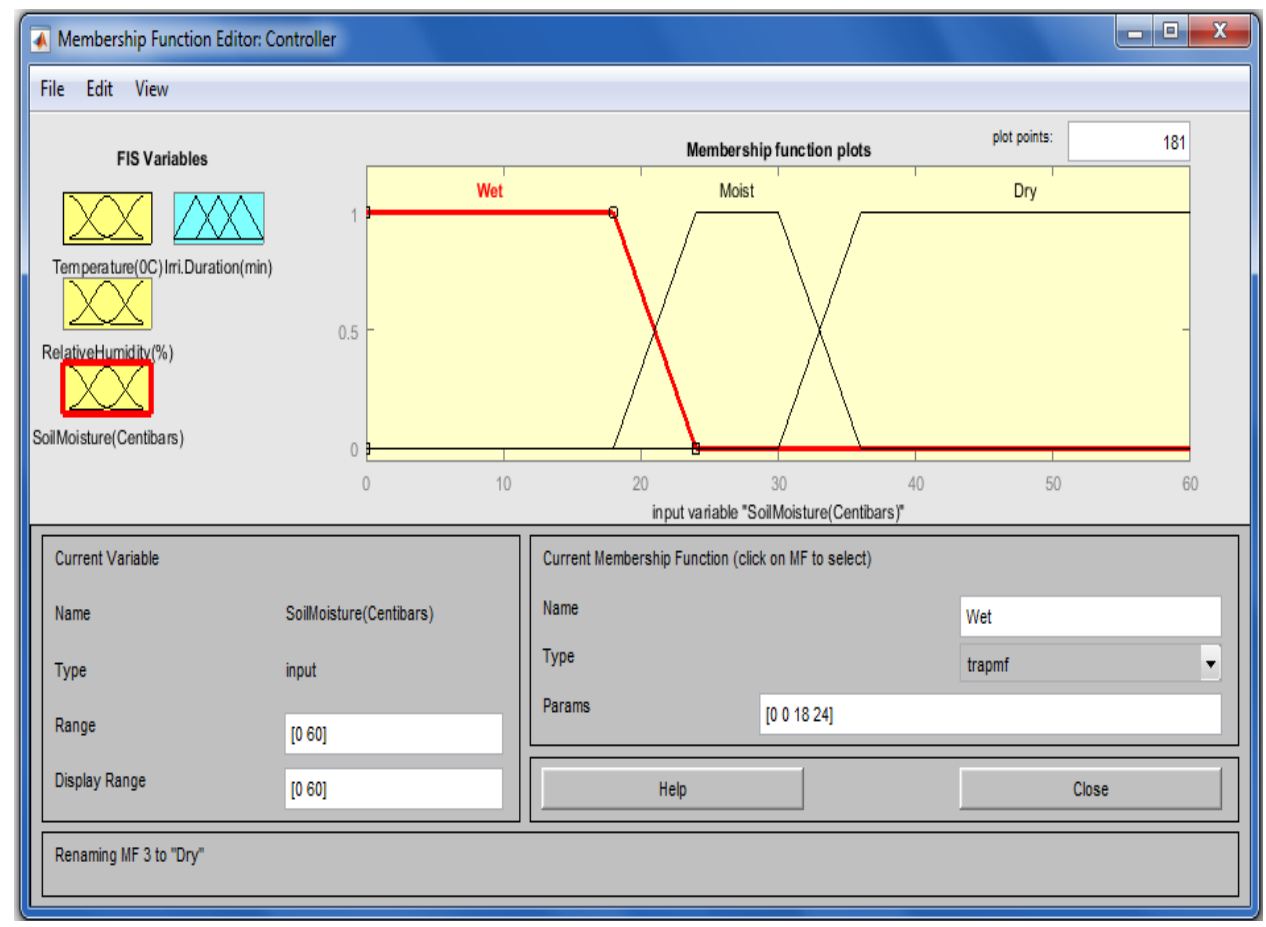

Fig. 8. Membership graph for input of soil moisture content, centibars.

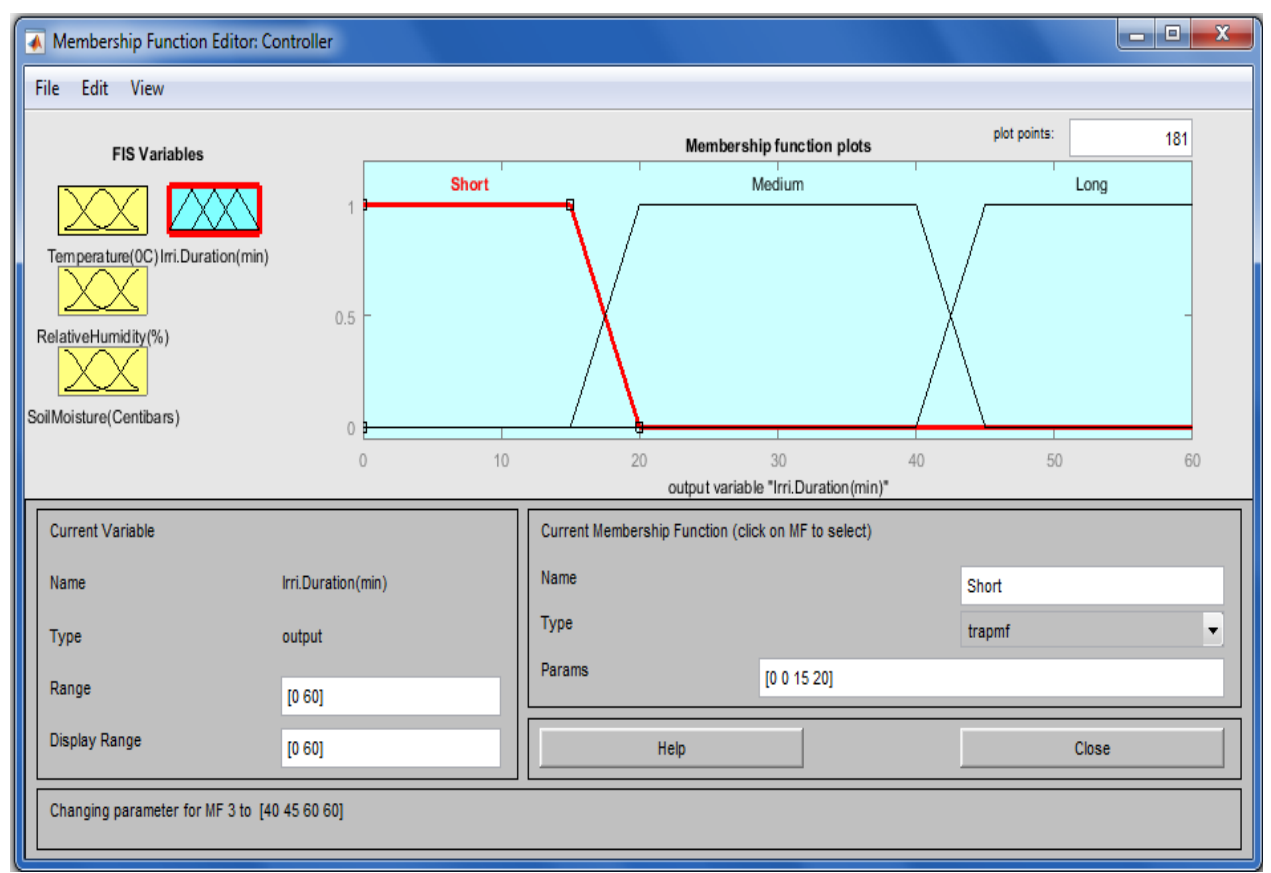

Fig. 9. Membership graph for output of irrigation duration, min. 


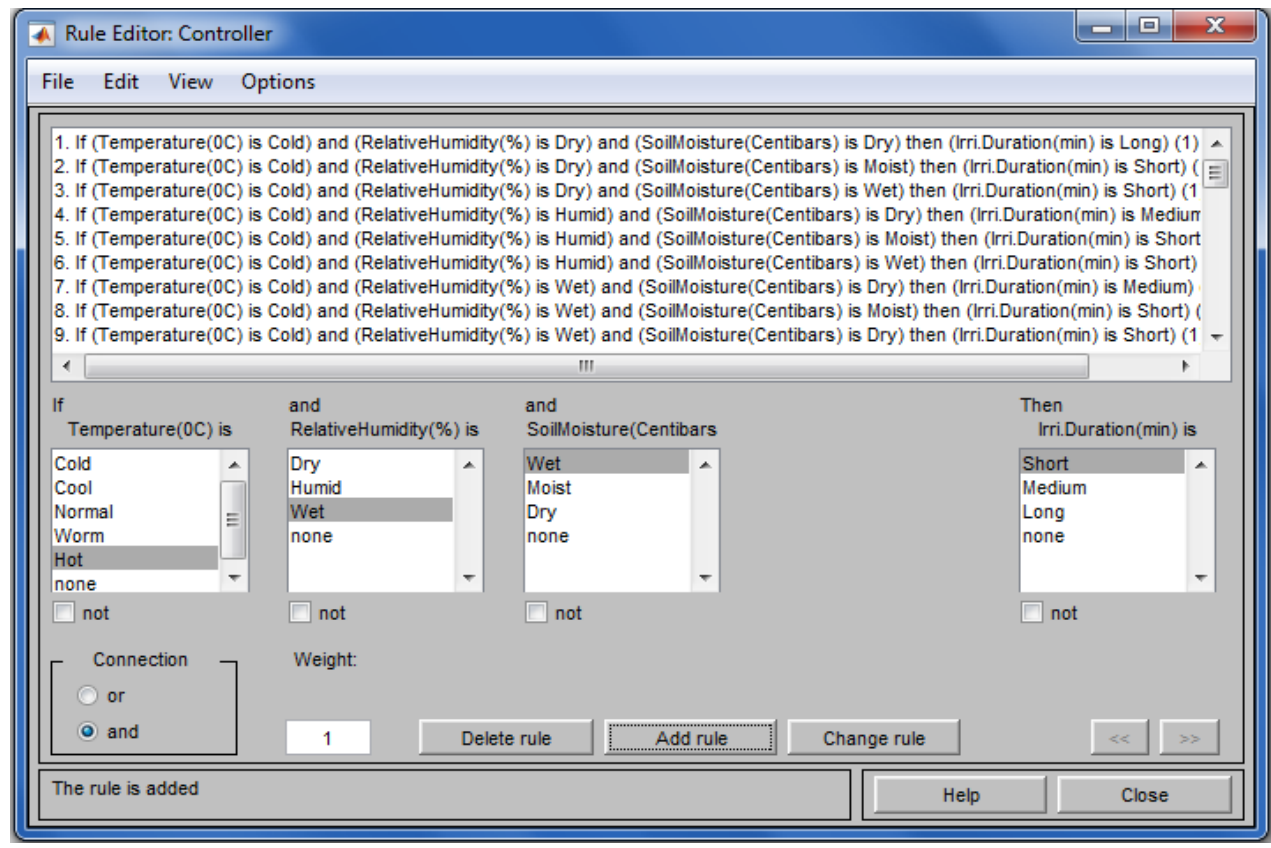

Fig. 10. Fuzzy Defined Rules for irrigation duration, min (45 rules).

\section{STEP 3: Fuzzy Inference System and Decision Making:}

The fuzzy inference system based on fuzzy rules (IF antecedent THEN consequent) that are devised by an expert knowledge base or through system input-output learning of system. FLC rules "mimics" human reasoning. Mamdani method is generally used in fuzzy inference technique. Fuzzy inference system used rules to generate fuzzy outputs, in this system there are 3 inputs against each input there is fuzzy linguistic variables as shown in Fig. 11 suggested by author.

\section{Step 4: Defuzzification:}

Defuzzification is an operation of transformation from a fuzzy set to a crisp number. For crisp input value, there are fuzzy membership for input variables, and each variable cause various fuzzy outputs cells that will used to activate or to be fired. Output will change into crisp value from this procedure of defuzzification.

Defuzzification can be done by different methods but most common technique is centroid method. The center of gravity or the centers of area (COA) defuzzification method were tested. The COA of a final membership function is defined as: 


$$
C O A=\frac{\sum_{t=0}^{n} x_{i} \mu\left(x_{i}\right)}{\sum_{t=0}^{n} \mu\left(x_{i}\right)}
$$

Where $x_{i}$ is the $i^{\text {th }}$ domain value and $\mu(x)$ is the membership grade.

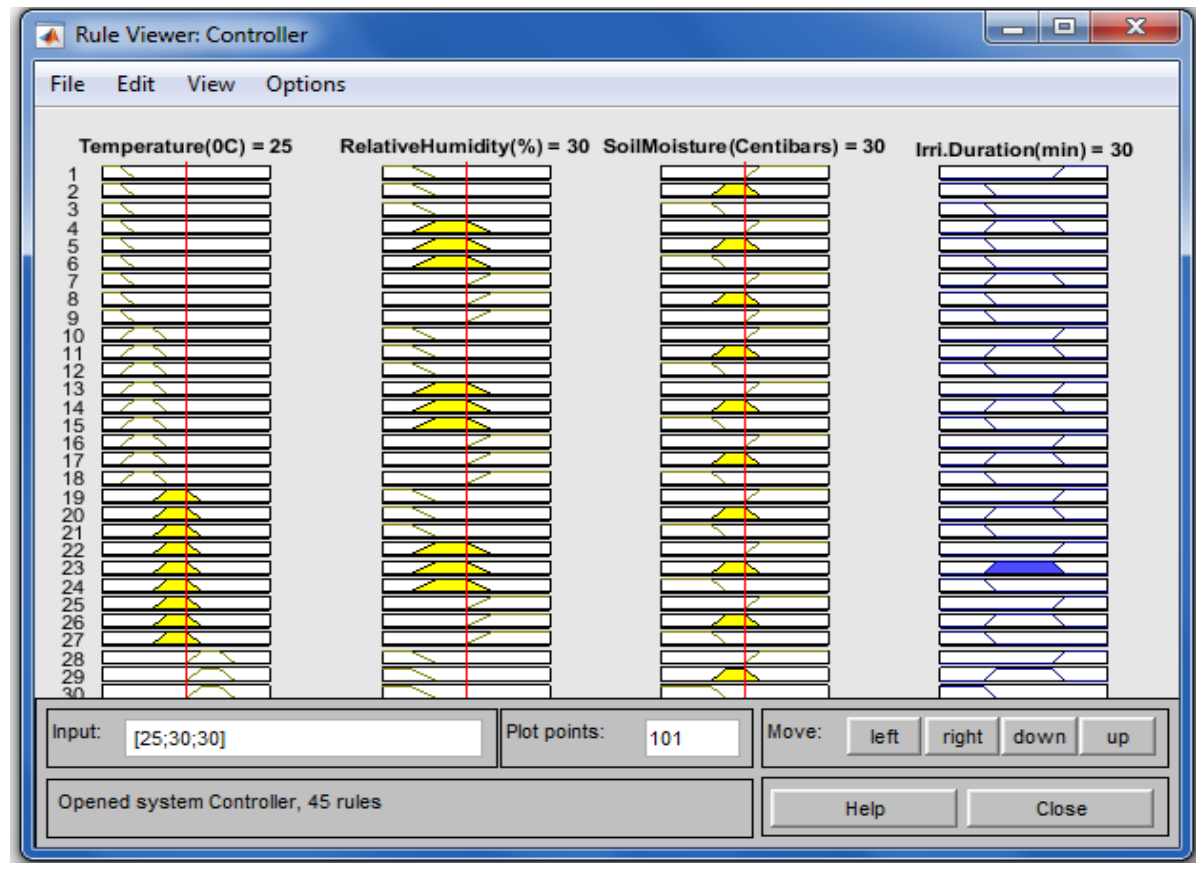

Fig. 11. Fuzzy inference system and rule viewer output for irrigation duration.

- Actual evapotranspiration ETa=(M2\%-M1\%)/100.db.D (mm) (Doorenbos and Pruitt, 1984)

Where $\mathbf{M}_{2}$ represents the moisture content after irrigation, \%.

$\mathrm{M}_{1}$ represents the moisture content before irrigation, $\%$.

db represents the specific density of soil.

D represents the mean depth, $\mathrm{mm}$.

- Water use efficiency WUE=MY/ETa $\quad\left(\mathrm{kg} \mathrm{m}^{-3}\right)$ (Howell et al., 2001)

Where MY represents the marketable yield of sugar beet and spinach, $\left(\mathrm{kg} \mathrm{ha}^{-1}\right)$.

- Irrigation water use efficiency IWUE=MY/IR ( $\left.\quad \mathrm{kg} \mathrm{m}^{-3}\right)$ (Michael, 1978)

Where IR represents the seasonal applied irrigation water, $\left(\mathrm{m}^{3}\right)$ (Table 6). 


\section{RESULTS AND DISCUSSION}

\section{The relationship between Air Temperature and other membership function:}

Fuzzy surface Fig. 12 and 13 shows that the defuzzification relationship between temperature and other membership function effect on the irrigation duration ( $\mathrm{min}$ ), the increasing of temperature degrees are followed by evaporation and transpiration of both of soil and plant, the soil evaporation causes the water losses specially in the highest temperatures degrees and reduces the efficiency of irrigation performance thus, increasing irrigation duration, As a consequence, there will be a salt stress on the plant according to the soil salt concentration increasing as a result of water losses by evaporation.

\section{Effect of IRM and HA on applied irrigation water of crops under SDI and SSDI:}

The data in Fig. 14 pointed out that the sugar beet roots and spinach leaves applied irrigation water (IR) $\mathrm{mm}$ season $^{-1}$ recorded a significant superiority of fuzzy logic controller (FLC) method compared with manual of irrigation water addition method (Manual) for all treatments. In addition, sub-surface drip irrigation (SSDI) had a clear effect on all treatments compared surface drip irrigation (SDI). The results showed the same trend for both seasons (2016/2017 and 2017/2018). The lowest values of sugar beet and spinach IR were 578.71 and $149.59 \mathrm{~mm}^{\text {season }}{ }^{-1}$ respectively, for the $1^{\text {st }}$ season. While, were 554.35 and $146.71 \mathrm{~mm}^{\text {season }}{ }^{-1}$ respectively, for the $2^{\text {nd }}$ season under FLC, HA $=15 \mathrm{~kg} \mathrm{ha}^{-1}$ and SSDI treatment. The highest values of sugar beet and spinach IR were 780.94 and $216.44 \mathrm{~mm} \mathrm{season}{ }^{-1}$ respectively, for both seasons under manual of irrigation water addition method (Manual) for all treatments. These results may be attributed to that using FLC method save applied irrigation water. Through gave crops requirements of irrigation water added based on soil moisture case and climate conditions moreover, SSDI system decreases water losses by evaporation from surface soil. Through, burial of irrigation lines at depth $25 \mathrm{~cm}$. It is also, the humic acid application rates increasing storage capacity in sandy soil which, saving a lot of applied irrigation water; these results are consistent with the findings of Hussain et al., (2011), Anand and Perinbam (2014) and Hamouda et al., (2017). 


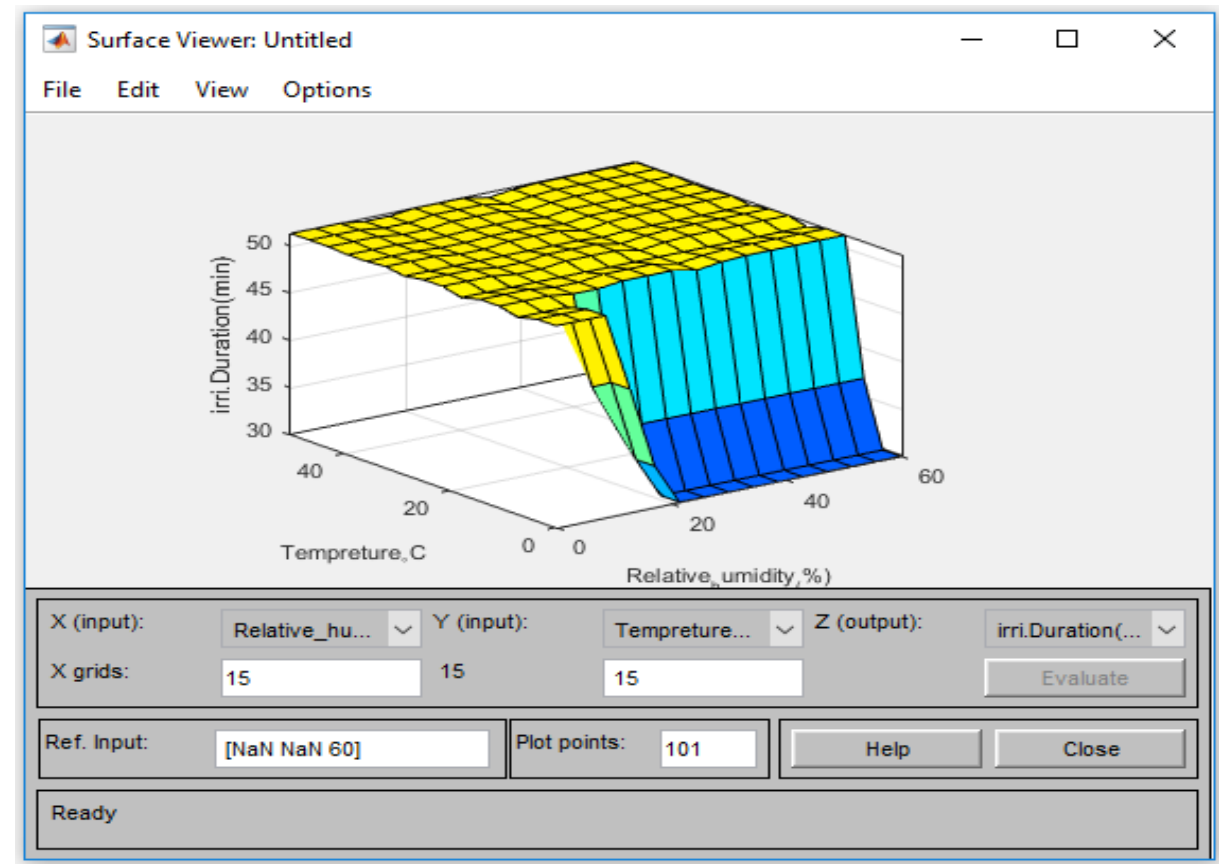

Fig.12. Effect of temperature, ${ }^{0} \mathrm{C}$ and relative humidity, $\%$ on irrigation duration, min.

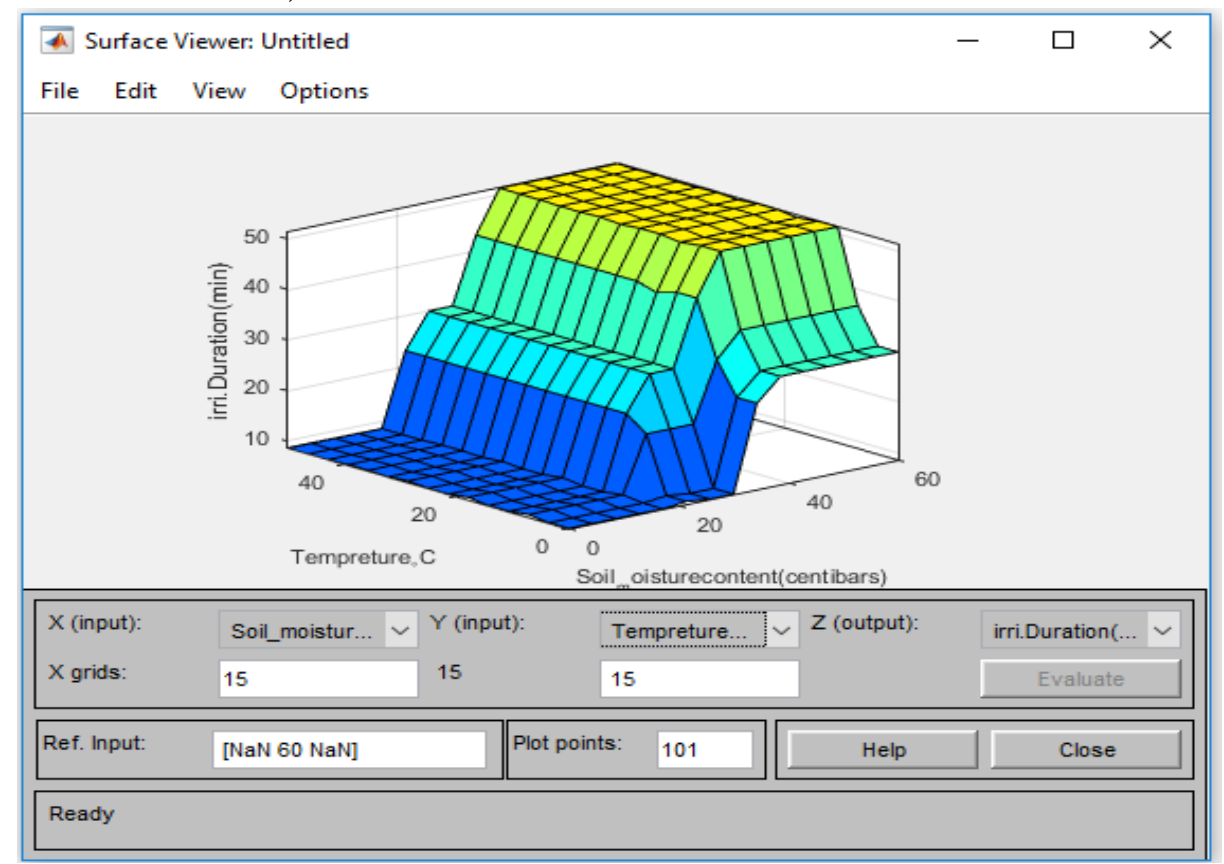

Fig.13. Effect of temperature, ${ }^{0} \mathrm{C}$ and soil moisture content, centibars on irrigation duration, min. 


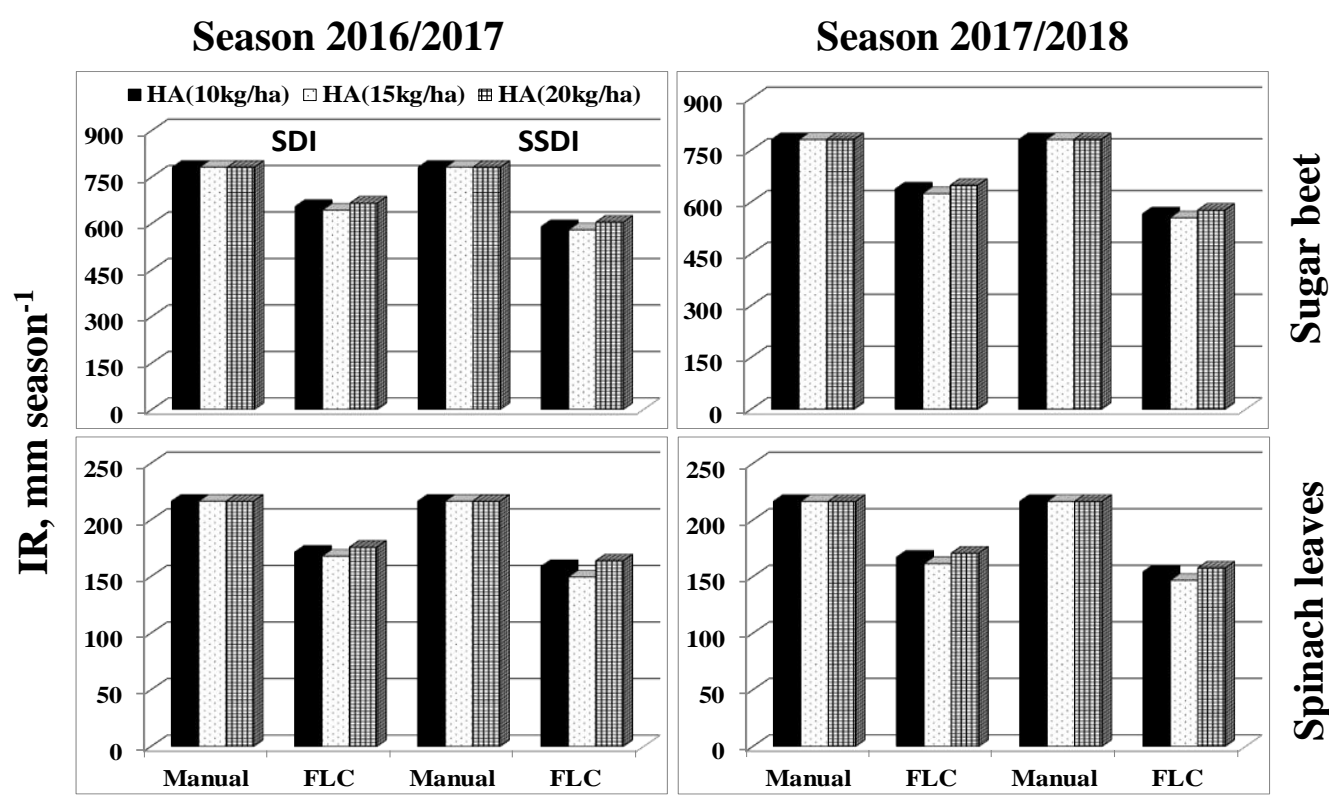

Irrigation water addition methods "IRM"

Fig. 14. Effect of irrigation water addition methods "IRM" and humic acid application rates "HA" $\left(\mathrm{kg} \mathrm{ha}^{-1}\right)$ on applied irrigation water "IR" mm season $^{-1}$ of sugar beet roots and spinach leaves under surface and subsurface drip irrigation systems for season 2016/2017- 2017/2018.

\section{Effect of IRM and HA on studied quality parameters of crops under SDI and SSDI:}

\subsection{Sugar beet roots:}

The data in Fig. 15 showed that the studied quality parameters for sugar beet roots such as sucrose (S) \%, purity of juice (P) \%, total soluble solid (TSS) $\%$ and white sugar yield (WSY) $\mathrm{Mg} \mathrm{ha}^{-1}$ increased with increasing humic acid application rates "HA" $\left(\mathrm{kg} \mathrm{ha}^{-1}\right)$ for all treatments. Also, data illustrated a significant superiority of fuzzy logic controller (FLC) method compared with manual of irrigation water addition method (Manual) for all treatments.

In addition, sub-surface drip irrigation (SSDI) had a clear effect on all treatments compared surface drip irrigation (SDI). The results recorded the same trend for both seasons (2016/2017 and 2017/2018). The highest S, P, TSS and WSY values were $21.62 \%, 85.92 \%, 22.29 \%$ and $11.39 \mathrm{Mg} \mathrm{ha}^{-1}$ respectively, for the $1^{\text {st }}$ season. 
Season 2016/2017
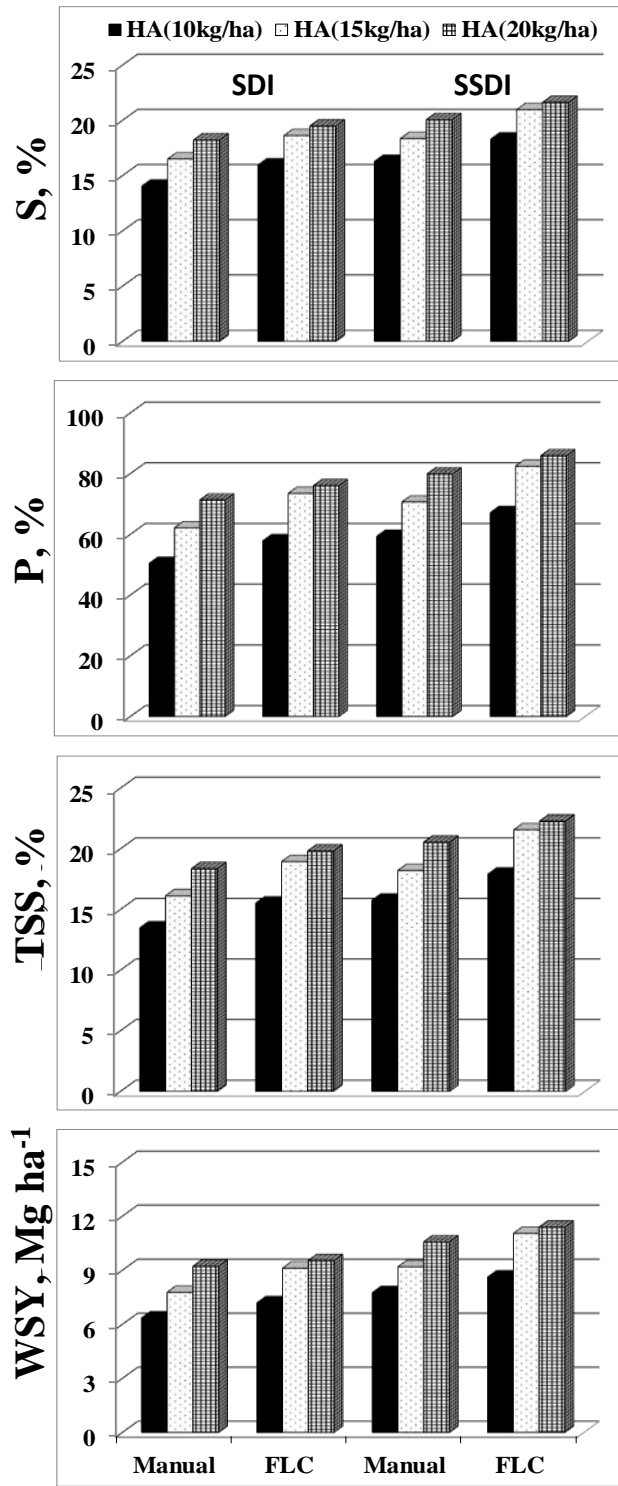

Season 2017/2018
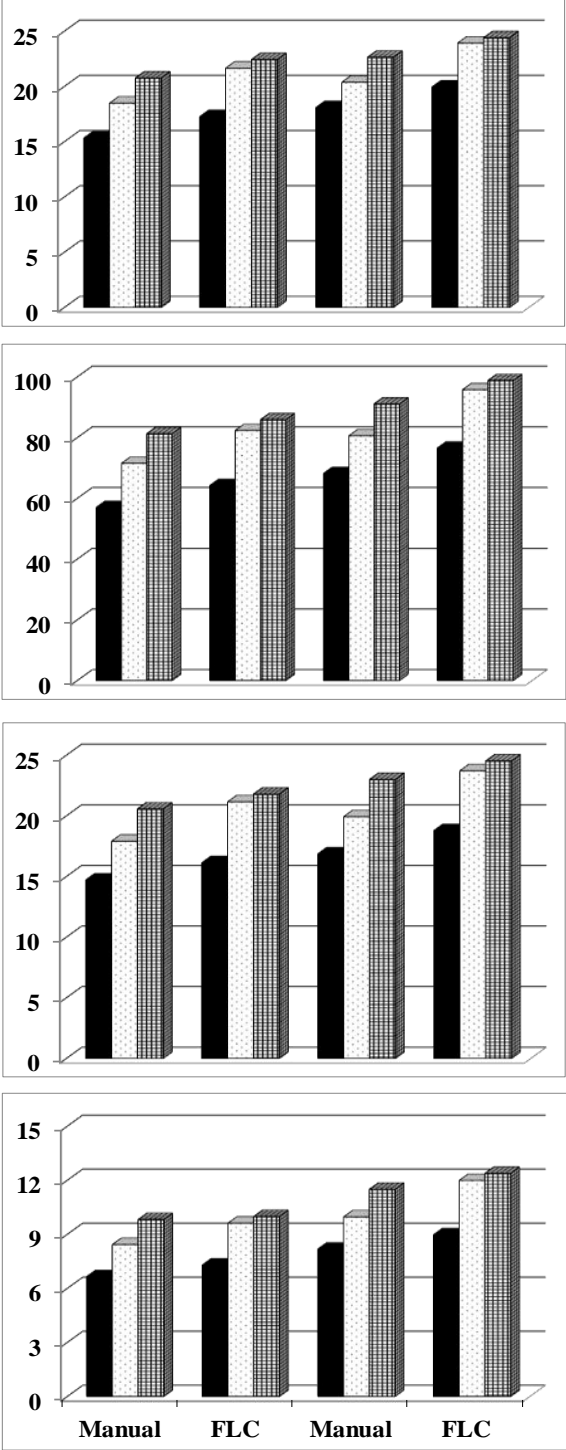

Irrigation water addition methods "IRM"

Fig. 15. Effect of irrigation water addition methods (manual \& FLC) and humic acid application rates "HA" $\left(\mathrm{kg} \mathrm{ha}^{-1}\right)$ on sucrose "S" (\%), purity of juice "P" (\%), total soluble solid "TSS" (\%) and white sugar yield "WSY" $\left(\mathrm{Mg} \mathrm{ha}^{-1}\right)$ for sugar beet roots under surface and subsurface drip irrigation systems at seasons 2016/20172017/2018. 
While, were $24.41 \%, 98.81 \%, 24.52 \%$ and $12.38 \mathrm{Mg} \mathrm{ha}^{-1}$ respectively, for the $2^{\text {nd }}$ season under FLC, HA $=20 \mathrm{~kg} \mathrm{ha}^{-1}$ and SSDI treatment. The lowest S, P, TSS and WSY values were $14.05 \%, 50.45 \%, 13.48 \%$ and $6.35 \mathrm{Mg} \mathrm{ha}^{-1}$ respectively, for the $1^{\text {st }}$ season. Meanwhile, were $15.32 \%$, $57.01 \%, 14.71 \%$ and $6.65 \mathrm{Mg} \mathrm{ha}^{-1}$ respectively, for the $2^{\text {nd }}$ season under Manual, HA $=10 \mathrm{~kg} \mathrm{ha}^{-1}$ and SDI treatment. These results are consistent with the findings of Masri et al. (2015).

\subsection{Spinach Leaves:}

The data in Fig. 16 reported that the studied quality parameters for spinach leaves (leaf area (LA) $\mathrm{cm}^{2}$, calcium content $(\mathrm{Ca}) \mathrm{mg} 100 \mathrm{~g}^{-1} \mathrm{FW}$, vitamin C content (VC) mg $100 \mathrm{~g}^{-1} \mathrm{FW}$ and $\beta$ carotene content $(\beta C) \mathrm{mg} 100 \mathrm{~g}^{-1} \mathrm{FW}$ increased with increasing humic acid application rates "HA" $\left(\mathrm{kg} \mathrm{ha}^{-1}\right)$ for all treatments. Also, data recorded a significant superiority of FLC method compared with Manual for all treatments. In addition, SSDI had a clear effect on all treatments compared SDI. The results showed the same trend for both seasons. The highest $\mathrm{LA}, \mathrm{Ca}, \mathrm{VC}$ and $\beta \mathrm{C}$ values were $35.62 \%$, $67.12 \%, 25.71 \%$ and $2.48 \mathrm{Mg} \mathrm{fed}^{-1}$ respectively, for the $1^{\text {st }}$ season. While,

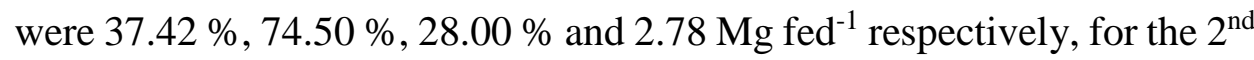
season under FLC, HA $=20 \mathrm{~kg} \mathrm{ha}^{-1}$ and SSDI treatment. The lowest LA, $\mathrm{Ca}, \mathrm{VC}$ and $\beta \mathrm{C}$ values were $18.05 \%, 37.19 \%, 14.19 \%$ and $1.31 \mathrm{Mg} \mathrm{fed}^{-1}$ respectively, for the $1^{\text {st }}$ season. Meanwhile, were $18.59 \%, 40.91 \%, 15.62$ $\%$ and $1.40 \mathrm{Mg} \mathrm{fed}^{-1}$ respectively, for the $2^{\text {nd }}$ season under Manual, $\mathrm{HA}=10$ $\mathrm{kg} \mathrm{ha}^{-1}$ and SDI treatment. These results are similar to these reported by Yasemin et al. (2016).

\section{Effect of IRM and HA on marketable yield of crops under SDI and SSDI:}

The data in Fig. 17 and 18 illustrated that the sugar beet roots and spinach leaves marketable yield ( $\mathrm{Ym}) \mathrm{Mg} \mathrm{ha}^{-1}$ increased with increasing humic acid application rates "HA" $\left(\mathrm{kg} \mathrm{ha}^{-1}\right)$ for all treatments. Also, data reported a significant superiority of FLC method compared with Manual method for all treatments. In addition, SSDI had a clear effect on all treatments compared SDI. The results showed the same trend for both seasons. The highest values of sugar beet and spinach Ym were 59.74 and $7.15 \mathrm{Mg} \mathrm{ha}^{-1}$ for the $1^{\text {st }}$ season, respectively, while, were 62.59 and $7.38 \mathrm{Mg} \mathrm{ha}^{-1}$ for the $2^{\text {nd }}$ season, respectively, under FLC, HA $=20 \mathrm{~kg} \mathrm{ha}^{-1}$ and SSDI treatment. 
Season 2016/2017

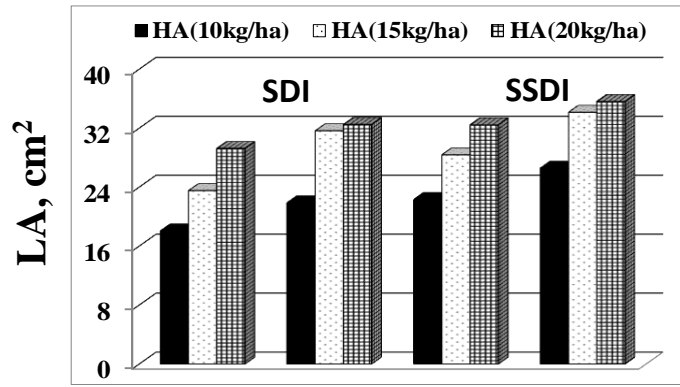

Season 2017/2018
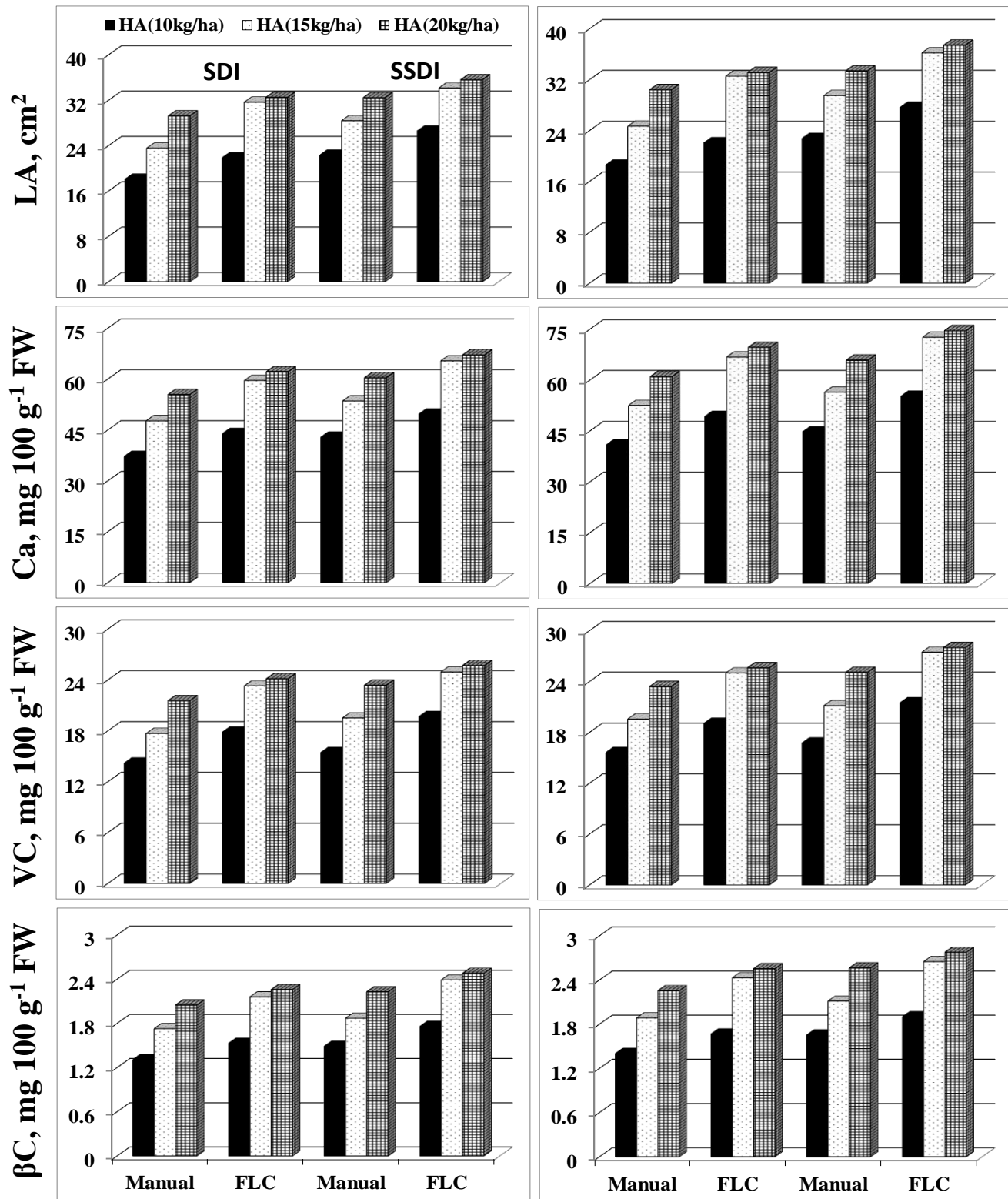

\section{Irrigation water addition methods "IRM"}

Fig. 16. Effect of irrigation water addition methods (manual \& FLC) and humic acid application rates "HA" $\left(\mathrm{kg} \mathrm{ha}^{-1}\right)$ on leaf area "LA" $\left(\mathrm{cm}^{2}\right)$, calcium content "Ca" (mg $\left.100 \mathrm{~g}^{-1} \mathrm{FW}\right)$, vitamin $\mathrm{C}$ content "VC" (mg $\left.100 \mathrm{~g}^{-1} \mathrm{FW}\right)$ and $\beta$ carotene content " $\beta C$ " (mg $100 \mathrm{~g}^{-1}$ $\mathrm{FW}$ ) for spinach leaves under surface and subsurface drip irrigation systems for season 2016/2017- 2017/2018. 
The lowest values of sugar beet and spinach Ym were 27.57 and $3.41 \mathrm{Mg}$ $\mathrm{ha}^{-1}$ for the $1^{\text {st }}$ season, respectively, while, were 28.69 and $3.47 \mathrm{Mg} \mathrm{ha}^{-1}$ for the $2^{\text {nd }}$ season, respectively, under Manual, HA $=10 \mathrm{~kg} \mathrm{ha}^{-1}$ and SDI treatment. These results may be attributed to that, using FLC method could be decrease deep percolation because it provides crops with their water needs in a timely manner though opening electric valves of irrigation network based on temperature, relative humidity and soil moisture content thus, providing large quantities of irrigation water added compared to Manual method. Moreover, using SSDI system helps to deliver the irrigation water directly, to the effective roots spread zone for both crop. Meanwhile, added HA rates in irrigation water increasing storage capacity in sandy soil and provided crops with macro nutrients N P K that make it healthy, all these factors led to increases marketable yield production for both crops, these results are in harmony with the finding of Sakellarioumakrantonaki et al. (2002), Anand and Perinbam (2014), Masri et al, (2015), Yasemin et al. (2016) and Hanaa et al. (2016).

\section{Effect of IRM and HA on actual evapotranspiration of crops under SDI and SSDI:}

Data in Fig. 17 and 18 indicated that the values of seasonal actual evapotranspiration (ETa) $\mathrm{mm}^{\text {season }}{ }^{-1}$ for sugar beet roots and spinach leaves recorded a significant superiority of FLC method compared with manual irrigation water addition method for all treatments. Also, SSDI had a clear effect on all treatments compared SDI. The results recorded the same trend for both seasons. The lowest values of sugar beet and spinach ETa were 450.41 and $133.17 \mathrm{~mm}^{\text {season }}{ }^{-1}$ respectively, for the $1^{\text {st }}$ season. While, were 418.95 and $126.84 \mathrm{~mm}_{\text {season }}{ }^{-1}$ respectively, for the $2^{\text {nd }}$ season under FLC, HA $=15 \mathrm{~kg} \mathrm{ha}^{-1}$ and SSDI treatment. The highest values of sugar beet and spinach ETa were 689.71 and $195.47 \mathrm{~mm} \mathrm{season}^{-1}$ respectively, for the $1^{\text {st }}$ season. While, were 671.25 and $187.51 \mathrm{~mm}^{-1}$ season ${ }^{-}$ ${ }^{1}$ respectively for the $2^{\text {nd }}$ season under Manual, HA $=20 \mathrm{~kg} \mathrm{ha}^{-1}$ and SDI treatment. These results may be attributed to that, using FLC method to controlled on irrigation network based on, climate and soil moisture conditions could be decreases irrigation water evaporation from surface soil compared to Manual method. moreover, using SSDI system by bury the irrigation lines at a depth $25 \mathrm{~cm}$ have a significant effect in reducing 
evaporation from surface soil compared to SDI system. Meanwhile, added HA rates it can conserve irrigation water and thus reduce evaporation from soil surface; these results are in agreement with that found by Anand and Perinbam (2014), Douh and Boujelben, (2011) and Hamouda et al., (2017).

\section{Effect of IRM and HA on water use efficiency of crops under SDI and SSDI:}

Data in Fig. 17 and 18 reported that the highest values of water use efficiency (WUE) for sugar beet roots and spinach leaves were (44.83 and $\left.17.60 \mathrm{~kg} \mathrm{~m}^{-3}\right)$; $\left(50.46\right.$ and $\left.19.33 \mathrm{~kg} \mathrm{~m}^{-3}\right)$ for both seasons respectively, under FLC, $\mathrm{HA}=15 \mathrm{~kg} \mathrm{ha}^{-1}$ and SSDI treatment. While, the lowest values were (13.76 and $\left.6.05 \mathrm{~kg} \mathrm{~m}^{-3}\right)$; (14.79 and $6.35 \mathrm{~kg} \mathrm{~m}^{-3}$ ) for both seasons, respectively, under Manual, $\mathrm{HA}=10 \mathrm{~kg} \mathrm{ha}^{-1}$ and SDI treatment. Meanwhile, the values of WUE for sugar beet roots and spinach leaves under FLC, HA $=15 \mathrm{~kg} \mathrm{ha}^{-1}$ and SSDI treatment were increased significantly by about (96 and $82 \%$ ) respectively, for the $1^{\text {st }}$ season. While, were (105 and $86 \%$ ) for the $2^{\text {nd }}$ season compared to that under the control treatment (Manual, HA $=20 \mathrm{~kg} \mathrm{ha}^{-1}$ and SDI). These results may be attributed to that using FLC method and SSDI system prevents surface soil evaporation, deep percolation and therefore saving a lot of irrigation water. Also, added HA rates increasing storage capacity in sandy soil and provided crops with macro nutrients N P K that make it healthy, all these factor led to increase marketable yield with decrease in actual evapotranspiration "ETa", these results were similar to those indicated by Abdel Reheem and Ferweez (2010), Anand and Perinbam (2014) and Yasemin et al. (2016).

\section{Effect of IRM and HA on irrigation water use efficiency of crops under SDI and SSDI:}

Data in Fig. 17 and 18 indicate that the highest values of irrigation water use efficiency (IWUE) for sugar beet roots and spinach leaves were (34.89 and $\left.15.67 \mathrm{~kg} \mathrm{~m}^{-3}\right) ;\left(38.13\right.$ and $\left.16.72 \mathrm{~kg} \mathrm{~m}^{-3}\right)$ for both seasons respectively, under FLC, HA $=15 \mathrm{~kg} \mathrm{ha}^{-1}$ and SSDI treatment. While, the lowest values were (12.01 and $\left.5.36 \mathrm{~kg} \mathrm{~m}^{-3}\right)$; (12.50 and $\left.5.45 \mathrm{~kg} \mathrm{~m}^{-3}\right)$ for both seasons, respectively, under Manual, $\mathrm{HA}=10 \mathrm{~kg} \mathrm{ha}^{-1}$ and SDI treatment. 

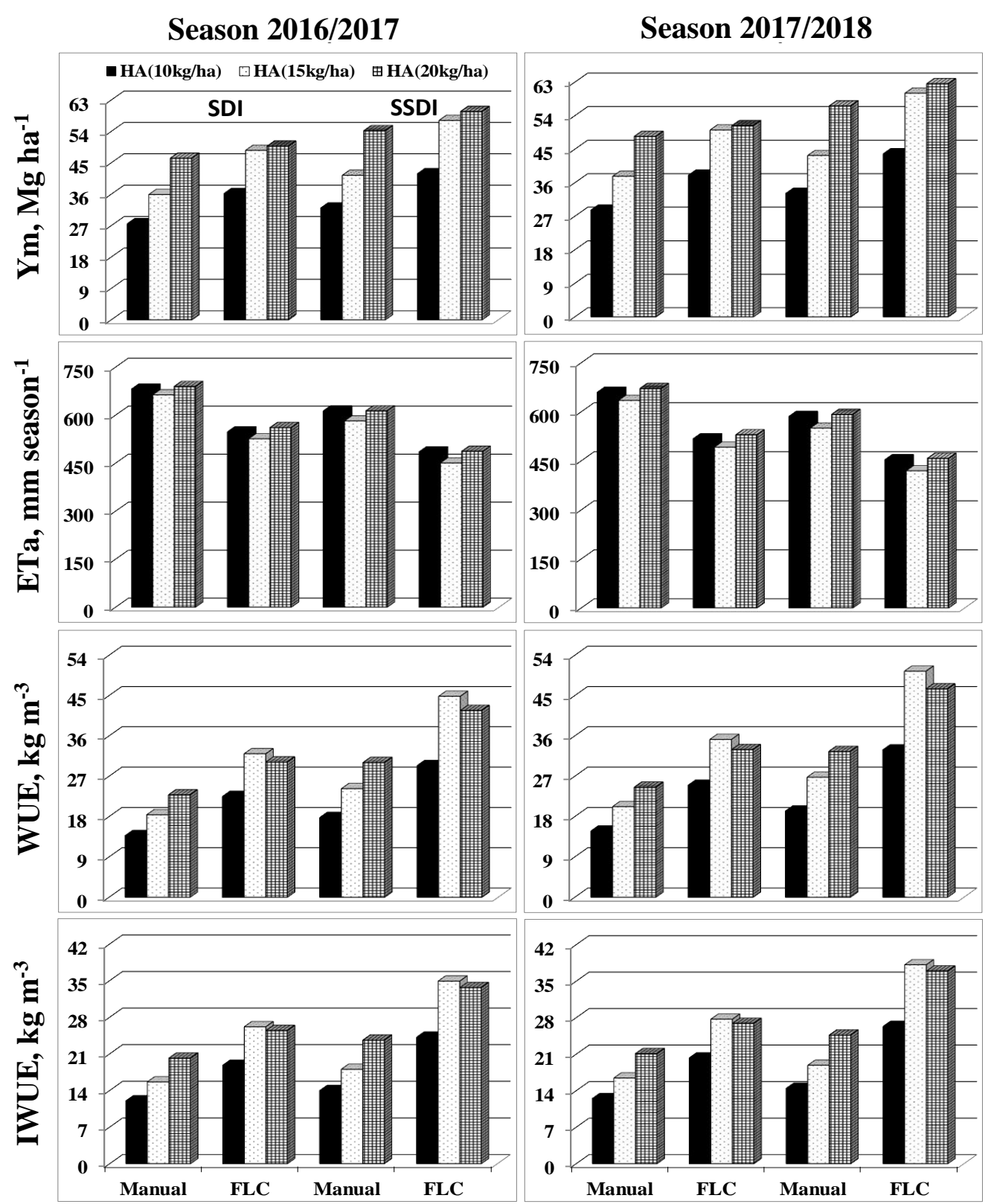

\section{Irrigation water addition methods "IRM"}

Fig. 17. Effect of irrigation water addition methods (manual \& FLC) and humic acid application rates "HA" $\left(\mathrm{kg} \mathrm{ha}^{-1}\right)$ on marketable yield "Ym" $\left(\mathrm{Mg} \mathrm{ha}^{-1}\right)$, seasonal actual evapotranspiration "ETa" $\left(\mathrm{mm}\right.$ season $\left.{ }^{-1}\right)$, water use efficiency "WUE" $\left(\mathrm{kg} \mathrm{m}^{-3}\right)$ and irrigation water use efficiency "IWUE" ( $\mathrm{kg}$ $\mathrm{m}^{-3}$ ) of sugar beet roots under surface and subsurface drip irrigation systems for season 2016/2017- 2017/2018. 


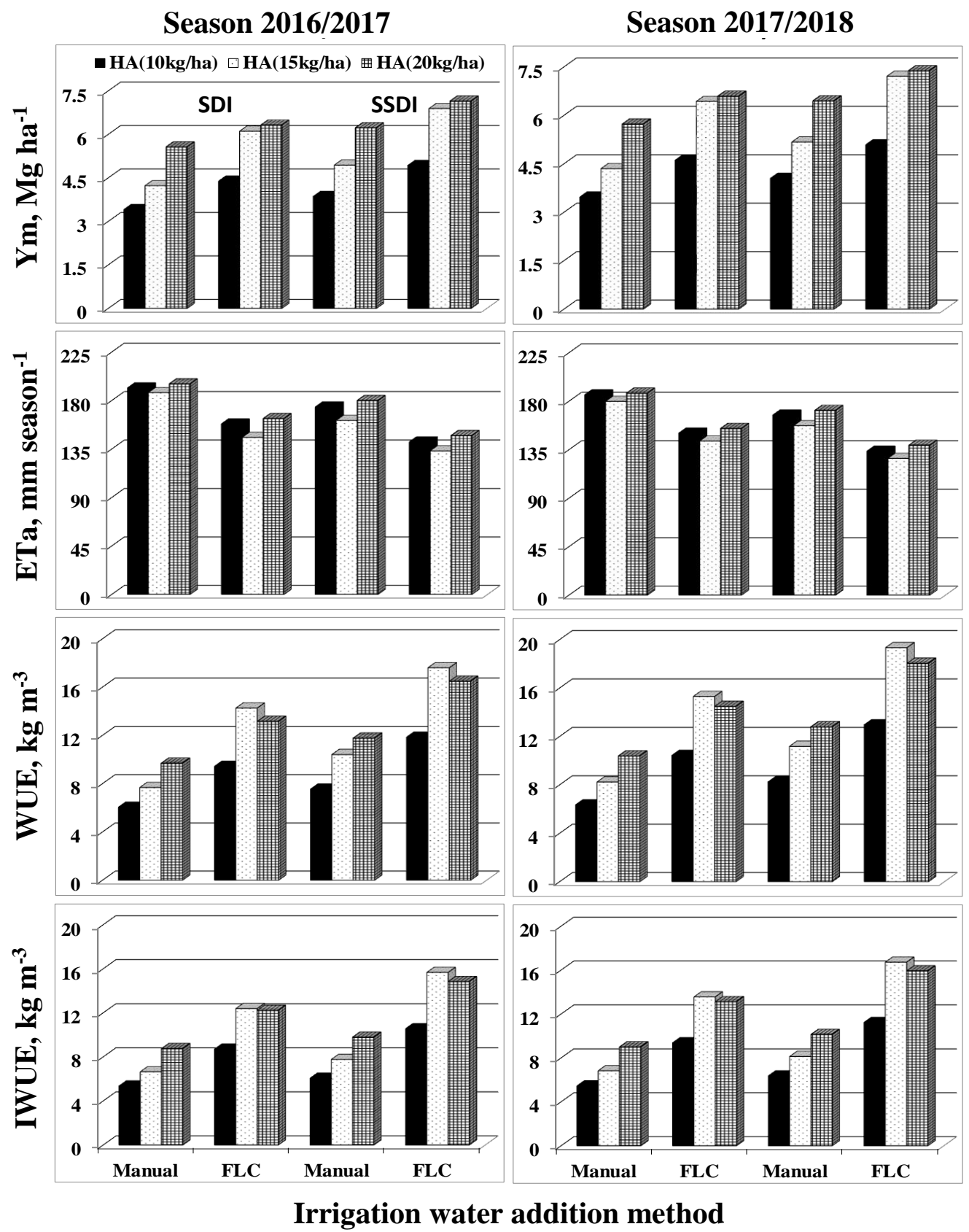

Fig. 18. Effect of irrigation water addition methods (manual \& FLC) and humic acid application rates "HA" $\left(\mathrm{kg} \mathrm{ha}^{-1}\right)$ on marketable yield "Ym" $\left(\mathrm{Mg} \mathrm{ha}^{-1}\right)$, seasonal actual evapotranspiration "ETa" $\left(\mathrm{mm}\right.$ season $\left.{ }^{-1}\right)$, water use efficiency "WUE" $\left(\mathrm{kg} \mathrm{m}^{-3}\right)$ and irrigation water use efficiency "IWUE" ( $\mathrm{kg}$ $\mathrm{m}^{-3}$ ) of spinach leaves under surface and subsurface drip irrigation systems for season 2016/2017- 2017/2018. 
Meanwhile, the values of IWUE for sugar beet roots and spinach leaves under FLC, HA $=15 \mathrm{~kg} \mathrm{ha}^{-1}$ and SSDI treatment were increased significantly by about (73 and $79 \%$ ) respectively, for the $1^{\text {st }}$ season. While, were $\left(81\right.$ and $86 \%$ ) for the $2^{\text {nd }}$ season compared to that under the control treatment (Manual, HA $=20 \mathrm{~kg} \mathrm{ha}^{-1}$ and SDI). These results may be attributed to that using FLC method and SSDI system prevents surface soil evaporation, deep percolation and therefore saving a lot of irrigation water. Also, added HA rates increasing storage capacity in sandy soil and provided crops with macro nutrients N P K that make it healthy, all these factor led to increase marketable yield with decrease in applied irrigation water "IR", these results are in accordance with Abdel Reheem and Ferweez (2010), Hussain et al., (2011) and Yasemin et al. (2016).

\section{CONCLUSIONS}

Results of the current study demonstrated beneficial effects of applied irrigation methods: (FLC and Manual) at different application humic acid rates under SDI and SSDI system on sugar beet and spinach production, quality growth parameters, seasonal ETa, WUE and IWUE for sugar beet roots and spinach leaves under Wadi El-Natrun sandy soil.

The study concluded that the marketable yield and studied quality parameters for sugar beet roots and spinach leaves gave the highest values under FLC, HA $=20 \mathrm{~kg} \mathrm{ha}^{-1}$ and SSDI treatment. On the other hand, the seasonal IR and ETa for crops gave the lowest values under FLC, HA =15 $\mathrm{kg} \mathrm{ha}^{-1}$ and SSDI treatment. Meanwhile, the values of WUE for both crops under FLC, HA $=15 \mathrm{~kg} \mathrm{ha}^{-1}$ and SSDI treatment increased significantly by about (96 and $82 \%$ ); (105 and $86 \%$ ) for both seasons, respectively, compared with that under the control treatment (Manual, HA $=20 \mathrm{~kg} \mathrm{ha}^{-1}$ and SDI). Finally, the values of IWUE for both crops under FLC, HA =15 $\mathrm{kg} \mathrm{ha}^{-1}$ and SSDI treatment increased significantly by about (73 and $79 \%$ ); (81 and $86 \%$ ) for both seasons, respectively, compared with that under the control treatment (Manual, $\mathrm{HA}=20 \mathrm{~kg} \mathrm{ha}^{-1}$ and SDI).

So, it is recommended to apply FLC, HA $=15 \mathrm{~kg} \mathrm{ha}^{-1}$ and SSDI treatment to cultivate sugar beet and spinach under Wadi El-Natrun conditions to save about 41 and 48 of applied irrigation water and increase marketable 
yield of both crops by about 28 and $26 \%$ compared to that under control treatment (i.e. Manual, $\mathrm{HA}=20 \mathrm{~kg} \mathrm{ha}^{-1}$ and SDI).

\section{REFERENCES}

Abdel Reheem, H.A. and H. Ferweez (2010) Explanatory study of the possibility of replacement sugar beet instead of sugar cane under limited water resources. Journal of Soil Sciences and Agricultural Engineering. Mansoura University. 1(9): 931-948.

Allen, R.G.; M. Smith; A. Perrier and L.S. Pereira (1998) Crop Evapotranspiration, guidelines for computing crop water requirements. FAO Irrigation and Drainage Paper No.56, FAO, Rome, Italy: 1-79.

Anand, J. and J.R. Perinbam (2014) Automatic irrigation system using Fuzzy Logic. AEIJMR 2 (8): 2348 - 6724.

Ayers, R.S. and D.W. Westcot (1994) Water Quality for Agriculture, Irrigation and Drainage Paper No 29, FAO, Rome, Italy.

Doorenbos, J. and W.O. Pruitt (1984) Crop Water requirements Guidelines for predicting crop requirements. FAO Irrigation and Drainage Paper No.24, FAO, Rome, Italy: 45-90.

Douh, B. and A. Boujelben (2011) Improving Water Use Efficiency for a Sustainable Productivity of Agricultural Systems Using Subsurface Drip Irrigation. Journal of Agricultural Science and Technology, ISSN 1939-1250, B1, 881-888.

Ed-dahhak, A.; M. Guerbaoui; Y. ElAfou; M. Outanoute; A. Lachhab; L. Belkoura and B. Bouchikhi (2013) Implementation of fuzzy controller to reduce water irrigation in greenhouse using lab-view. International Journal of Engineering and Advanced Technology Studies 1(2):12-22.

Hamouda, A.; A.G. Taj Eldain; Z. Dia and C. Hassan (2017) Wireless fuzzy controller for drip irrigation. International Journal of Advanced Research in Computer and Communication Engineering 6(1):86-89.

Hafez, M.M.; M.R. Shafeek; A.R. Mahmoud and A.H. Ali (2015) Beneficial effects of nitrogen fertilizer and humic acid on growth, yield and nutritive values of spinach (Spinacia olivera L.) Middle East Journal of Applied Sciences 5 (2): 597-603. 
Howell, T.A. (2001) Enhancing water use efficiency in irrigated agriculture. Agronomy J. Abst., 93: 281 - 289.

Hussain, M.H.; T.W. Min; S.F. Siraj; S.R. Rahim; N. Hashim and M.H. Sulaiman (2011) Fuzzy logic controller for automation of greenhouse irrigation system. Conference: 3rd CUTSE International Conference, At Miri, Sarawak, Malaysia.

Keller, J. and D. Karmeli (1974). Trickle irrigation design parameters. ASAE, 17 (4): 678-684.

Khan, F.; F. Shabbir and Z. Tahir (2014). A fuzzy approach for water security in irrigation system using wireless sensor network. Science International Journal (Lahore), 26(3):1065-1070.

Klute, A. (1986). Methods of soil analysis, Part (1). Physical and Mineralogical Methods-Agronomy monograph No. 9 ( $2^{\text {nd }}$ Edition). ASA and SSSA, Madison, WI, USA: 635 - 660.

Masri, M.I.; B.S. Ramadan; A.M. El-Shafai and M.S. El-Kady (2015). Effect of water stress and fertilization on yield and quality as affected by nitrogen levels and foliar application with micronutrients yield and quality of sugar beet under drip and sprinkler irrigation systems in sandy soil. International Journal of Agricultural Sciences. 5 (3): 414-425.

Melendez, D.G.; A.L. Lambraño; G.H. Ruiz; C. Fuentes; E.R. Garcia; C.O. Olvera; D.A. Lumbrerasc; T.M. Fernández and S. Verlinden (2011). Fuzzy irrigation greenhouse control system based on a field programmable gate array, African Journal of Agricultural Research. 6(11): 2544-2557.

Michael, A. (1978) Irrigation and theory practice. Vikas Pub. House PVT LTD, New Delihi.

Page, A.L.; R.H. Miller and D.R. Keeney (1982) Methods of soil analysis, part 2. Chemical and microbiological properties. Amer. Soc. of Agron, Madison, Wisconsin, USA.

Rassam, G.; A. Dadkhah; A.K. Yazdi and M. Dashti (2015) Impact of humic acid on yield and quality of sugar beet (Beta vulgaris L.) grown on calcareous soil. Notulae Scientia Biologicae 7(3):367-371. DOI: $10.15835 /$ nsb.7.3.9568. 
Ronghua, J.; Q. Lijun and H. Zicheng (2016). Design of Fuzzy control algorithm for precious irrigation system in greenhouse. Computer and Computing Technologies in Agriculture (CCTA). 370 (Part III): 278-283.

Sakellariou-makrantonaki, M.; D. Kalfountzos and P. Vyrlas (2002) Water saving and yield increase of sugar beet with subsurface drip irrigation. Global Nest: International Journal. 4, (2-3): 85 -91.

Smith, M. (1992) CROPWAT a computer program for irrigation plans and management and ETo calculation using Penman-Montieth method, FAO Irrigation and Drainage, Rome, Italy: 46: 112-140.

Snedecor, G.W. and W.G. Cochran (1989) Statistical methods, $8^{\text {th }}$ Ed., Iowa State Univ. Press, Iowa. USA: 476.

Singh, H.; M.G. Madan; M. Thomas; H. Zeng-Guang; K.G. Kum; M.G. Ashu and A.Z. Lotfi (2013) Real-life applications of fuzzy logic. Advances in Fuzzy Systems.Vol. 2013, Article ID 581879, 3 pages http://dx.doi.org/10.1155/2013/581879.

Yasemin, K.; U. Sahin; F.M. Kiziloglu and M. Sengul (2016) Yield and quality responses of drip-irrigated spinach to different irrigation quantities in a semi-arid region with a high altitude. Journal of Central European Agriculture. 17(3): 763-777.

$$
\begin{aligned}
& \text { الملخص العربي } \\
& \text { نموذج مقترح لتقدير الأحتياجات الأروائية }
\end{aligned}
$$

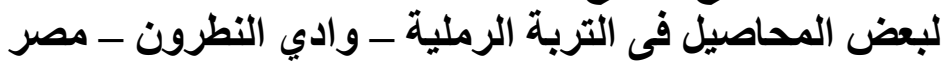

$$
\begin{aligned}
& \text { على أحمد على عبد العزيز* }
\end{aligned}
$$

جريت هذه التجربة فى منطقة وادى النطرون بمحافظة البحيرة - جمهورية مصر العربية وكانت

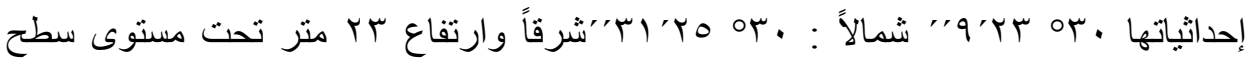

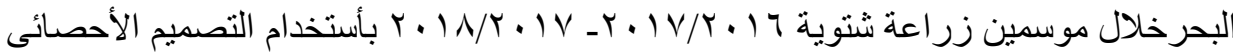

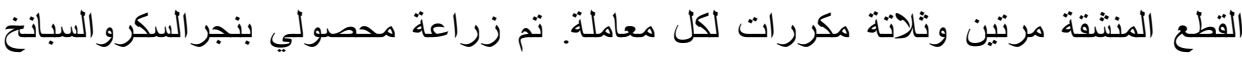

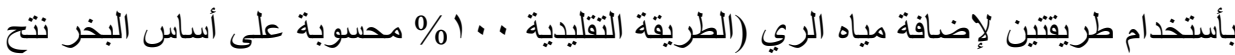

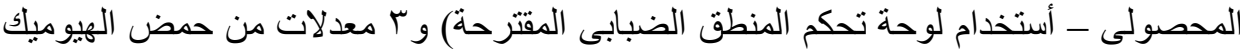

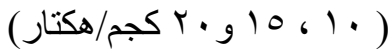

*قسم كيمياء وطبيعة الأراضى - مركز بحوث الصحراء. 


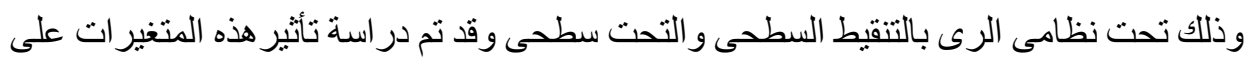

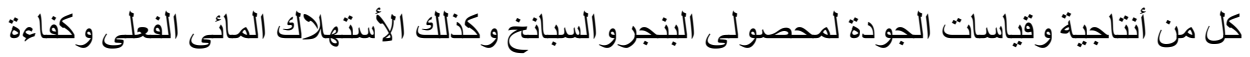

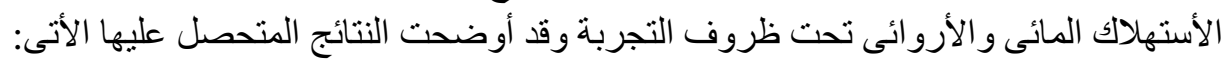

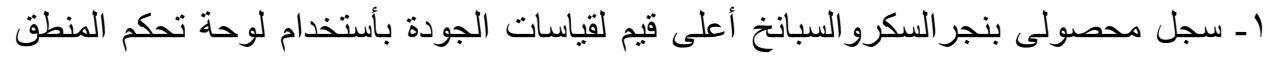

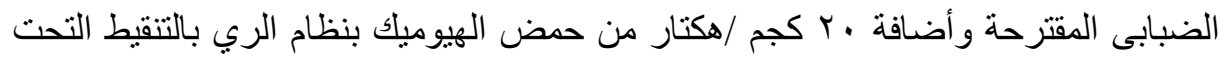

$$
\text { سطحي لكلا الموسمين. }
$$

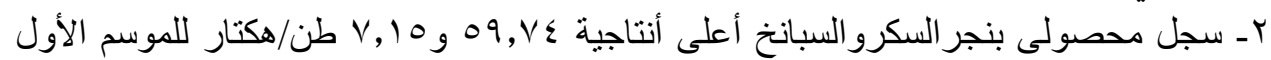

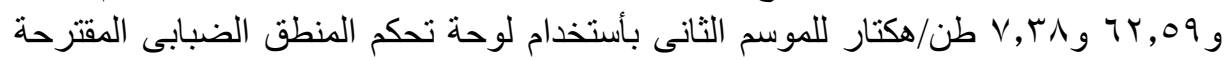

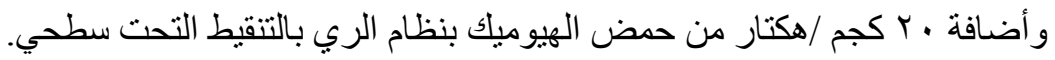

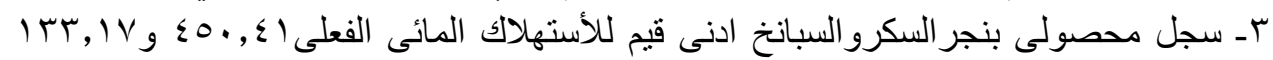

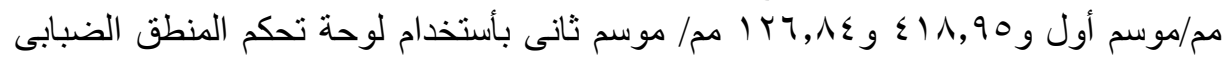

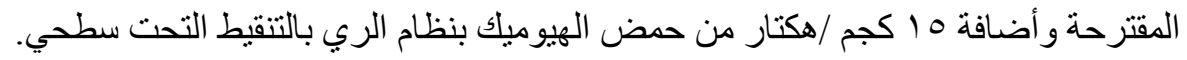

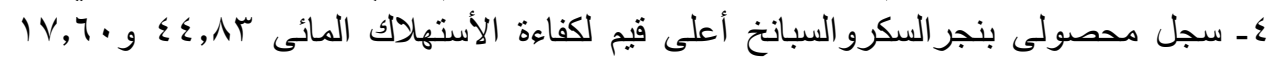

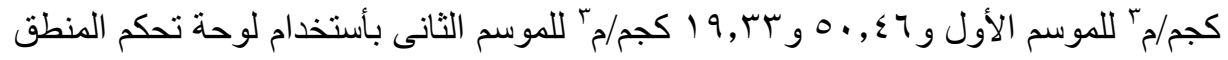

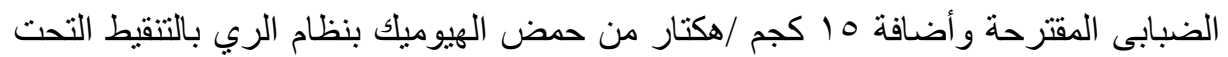
سطحي.

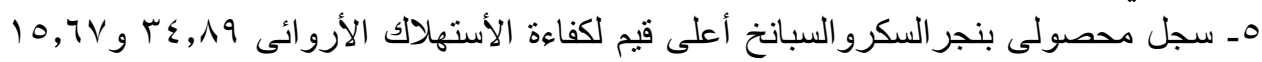

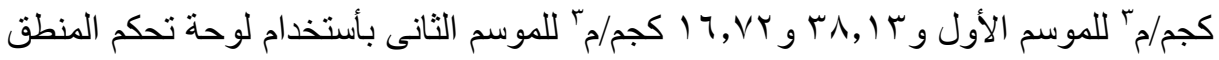

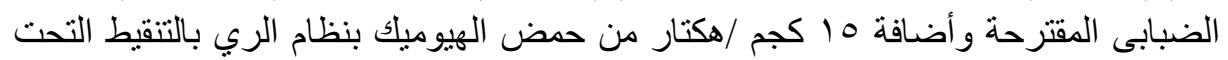

$$
\text { سطحي. }
$$

لذا يمكن التوصية بزر اعة محصولى بنجر السكرو السبانخ بأستخدام لوحة تحكم المنطق الضبابى الته

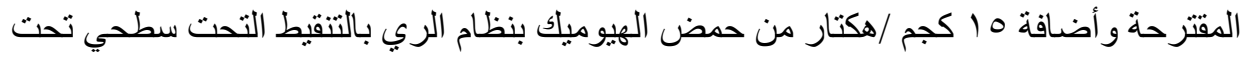

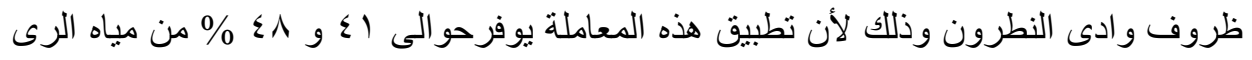

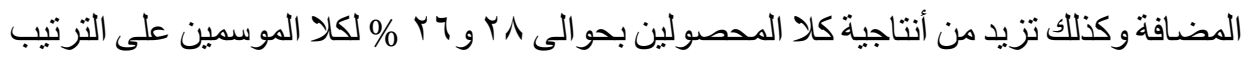

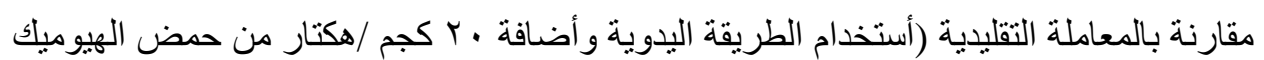
بنظام الري بالتنقيط سطحي). 